\title{
アルカリシリカ反応が道路橋RC床版の 耐疲労性に及ぼす影響
}

\begin{abstract}
本研究は，アルカリシリカ反応(ASR)が道路橋RC床版の耐疲労性に及ぼす影響について実験的に検討し たものである. 実物大に近いRC床版を作製し, 環境条件の異なるASR促進試験を行った後, 水の作用の 有無に着目した輪荷重走行試験を行い，各種要因がRC床版の耐疲労性に及ぼす影響を検討した。その際， 所定の輪走行回数におけるRC床版のたわみやひび割れの発生状況を調査すると共に, 小型加振器を用い た強制振動試験を行い，ASRおよび疲労による床版の剛性低下を評価した，その結果，ASRを生じたRC床 版の耐疲労性はASRによる損傷状況に依存することを明らかにし，ASRによるケミカルプレストレスの導 入およびひび割れの進展と水の作用が相互に影響することを示した. さらに，これらの影響を評価する上 で振動試験が有効であることを明らかにした。
\end{abstract}

Key Words : RC bridge deck, fatigue resistance, alkali silica reaction, wheel load trucking test, chemical prestress

\section{1. はじめに}

道路橋鉄筋コンクリート床版(以下，RC床版)は，今な お，疲労による著しい損傷事例が多く報告されている. 輪荷重単独による疲労損傷は，松井の研究1において， 床版下面のひび割れの進行過程により整理がなされ，そ の結果, 床版下面からの点検により疲労損傷度を評価す ることが可能となり，現行の維持管理方法 ${ }^{2} に$ 適用され ている. 一方，東北地方をはじめとする積雪寒冷地では，
凍結防止剂(主に $\mathrm{NaCl}$ )の量散布に伴い，コンクリート 構造物の塩害, 凍害によるスケーリング, およびアルカ リシリカ反応(以下，ASR)を促進させることが知られて おり, 近年, 寒冷地におけるRC床版の早期劣化が社会 問題になりつつある ${ }^{33)}$.

こうした材料劣化と疲労との複合劣化を受けるRC床 版の劣化機構を解明するため，これまで多くの研究機関 で材料劣化を受けるRC床版の耐疲労性に関する研究が 行われてきた ${ }^{5-7)}$. このうち, 著者らは, 塩害がRC床版 
の而疲労性に与える影響について実験的・解析的に検討 し，鉄筋腐食がRC床版の耐疲労性に及ぼす影響は下側 鉄筋に比べ上側鉄筋の方が大きいといった新たな知見を 報告している8)．また，凍害がRC床版の耐疲労性に与え る影響については, 数多くの研究成果 ${ }^{9910)}$ が報告されて おり，三田村らの研究5により，床版上面のスケーリン グ劣化深さが進行するに伴い， RC床版の而疲労性が低 下するといった報告がある.

このように，塩害や凍害がRC部材の而疲労性に与え る影響については研究が行われており, 劣化機構の解明 が進められつつある.

一方で，ASRによって劣化したRC部材の耐荷性につ いては，適切に鉄筋が配置されている場合，ASRによる コンクリートの膨張を鉄筋が拘束することでケミカルプ レストレスが生じ，ASRが部材の而渮力に与える影響は 比較的小さいとされていた ${ }^{11)}$. 特に，床版部材では，橋 脚や橋台に比べ部材厚が薄く乾燥状態にあることから,

ASRの発生は稀であるといった知見が一般的であった ${ }^{11)}$. しかしながら, 凍結防止剂の散布が本格化して以降,

ASRにより過大な膨張が発生した構造物の劣化事例が 徐々に増加している. ASRにより劣化した構造物の調査 結果により，ASRによる過大な膨張を起因として，コン クリートの強度低下や鉄筋とコンクリートの付着力の低 下，さらには曲げ加工部や圧接部での鉄筋破断などの損 傷が確認されている ${ }^{12)}$ 14)。 また，近年ではASRの発生が 比較的少ないとされていた床版部材においてもASRによ る損傷事例が増加しており, 架替えを余儀なくされた RC床版も少なくない ${ }^{15)}$. 床版部材では，主鉄筋および配 力鉄筋方向以外の鉄筋拘束がないため, ASRが生じた場 合では床版厚さ方向に大きな膨張が生じ，これが床版の 構造性能に大きな影響を及ぼすと考えられる め, ASRがRC床版の而疲労性に及ぼす影響を究明し， これに立脚した構造物の維持管理方法を構築することが 急務となっている.

ASR RC部材の耐荷性・耐疲労性について検討した 既往の研究では， RCはりの主鉄筋方向におけるコンク

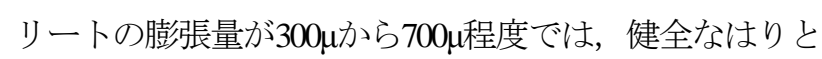
同程度の耐荷性・耐疲労性を有するといった報告がなさ れている ${ }^{17 \sim 19)}$. また，ASRによる劣化を与えたRCはり の曲げ載荷試験においては，ケミカルプレストレスの影 響により，曲げひび割れおよびせん断ひび割れ発生荷重 が増加したといった報告がされるなど，ASRによるコン クリートの膨張や，これに伴うひび割れが生じていても 而渮性がほとんど低下しないといった報告が多い20) 22). 一方で，異常膨張による鉄筋破断の影響を受けたRCは りの曲げ載荷試験や，コンクリートを $12000 \mu$ 程度と過大 に膨張させたRC床版供試体でのせん断疲労実験では,
RC部材の而渮性・耐疲労性が健全な供試体よりも低下

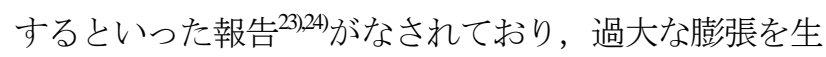
じた場合では，ASRの影響によってRC床版の構造性能 が低下するといった知見も広まりつつある.

しかし，ASRを受けるRC部材の構造性能に関する既 往の研究例は総じて少なく, 未解明な部分が多い現状に ある. 特に，RC床版を対象とした研究例は極めて少な く，実験データも十分でない。また，ASRがRC部材の 耐荷性・耐疲労性に及ぼす影響を検討した既往の研究25) では，高温高湿度環境下において，高濃度の塩分をRC 部材に供給するといった方法によりASRを急激に促進さ せているものがほとんどである.このようなASRを急激 に促進させる試験では，実験期間の短縮に関しては有効 であるものの，一般にASRによる構造物の劣化が顕在化 するには数年から数十年要することを考えると, 実環境 に即した試験とは言い難い"11)。すなわち, 凍結防止剂散 布環境下においてASRにより劣化したRC床版の耐疲労 性に関する研究は，未だ実構造物に近い状態では再現さ れておらず，ASRによるコンクリートの劣化と而疲労性 との詳細な関係をはじめとする劣化現象の把握と劣化機 構の解明には至っていないと思われる.

そこで本研究では，材料劣化のうちASRを取り上げ， これがRC床版の耐疲労性に与える影響を実験的に検討 した。 まず反応性粗骨材を使用して作製した実物大に近 いRC床版に対して，環境条件の異なるASR促進を実施 することで，ASRによるコンクリートの膨張速度および 損傷状況の異なる劣化を生じさせた. そして, ASRによ る劣化を受けたRC床版供試体による輪荷重走行試験よ り，ASRによるコンクリートの劣化を受けたRC床版の 而摭労性を評価した。 また，輪荷重走行試験の各段階に おいて, 小型加振器を励振器としたRC床版の厚さ方向 の強制振動試験を実施し， RC床版内部の損傷レベルを 定量的に評価することで，ASRがRC床版の耐疲労性に 及ぼす影響について実験的に検討した.

\section{2. 供試体および実験概要}

\section{（1）実験条件}

表-1に実験条件を示す，本研究では，ASRがRC床版 の而疲労性に与える影響を検討するため, 同一材料・配 合で作製したRC床版供試体に対し，高温高湿度環境下 においてASRによるコンクリートの膨張を早期に促進さ せる試験(以下, 急速試験) と, 屋外曝露環境下において 比較的緩やかにASRを促進させる試験(以下，緩速試験) といった2種類の促進試験を実施した．また，急速試験 では試験期間を変更することで，ASRによるコンクリー 
トの劣化程度に差をつけた．さらに，輪荷重走行試験時 における水張りの有無を実験条件として加えた計4条件 を実験条件とした。

具体的には，1) 本実験の基準となる，ASR促進を行わ ない健全相当のRC床版供試体(以下， N-d) と，2) ASRが, 而披労性に与える影響を確認するため，急速試験を41日 間実施したRC床版供試体(以下，R-d)，3) 急速試験を59 日間実施することで ASRの劣化度をR-dよりも進展させ， さらにASRにより発生したひび割れに水が浸入すること で，耐疲労性を急激に低下させることを想定して，輪荷 重走行試験時に床版上面に真水を湛水させる水張り試験 を実施したRC床版供試体(以下，R-w)，4) ASRを緩やか に進行させるため，260日間の緩速試験を実施し，さら にR-w同様に走行試験時に水張りを行ったRC床版供試体 (以下，S-w)の計4条件である.

\section{（2） 供試体概要}

図-1に，供試体形状を示す．なお，図中には鉄筋ひず みゲージおよび埋込み型ひずみ計の位置を併記している。 図より，供試体は3,000 $\mathrm{mm} \times 2,000 \mathrm{~mm} \times 160 \mathrm{~mm} の$ 複鉄筋 $\mathrm{RC}$ 床版である. 主鉄筋と配力鉄筋には各々D16(SD295A)と D13(SD295A)を用い，主鉄筋のかぶりは上面，下面とも に支間10m以下のRC床版の最小かぶりである30mmとし $た^{20}$. 引張側の主鉄筋之配力鉄筋の配置間隔は，それぞ れ150mmと125mmである．鉄筋ひずみゲージは，床版中 央に加え，床版中央より橋軸方向に $900 \mathrm{~mm}$ 位置て鉄筋 のリブに貼付した．また，鉄筋により拘束される方向と 自由膨張方向におけるコンクリートの膨張挙動を評価す るため，橋軸方向(以下， $\mathrm{x}$ 方向)，橋軸直角方向(以下，y 方向), 鉛直方向(以下，z方向)の各コンクリートひずみ を計測するものとし，各床版中央位置で3方向に埋込型 ひずタ計を埋設し，R-dおよびR-wについては床版端部 付近にも同様にひずみ計を埋設した(写真-1).

表-2に，コンクリートの示方配合を示寸．コンクリー トはレディーミクストコンクリートであり, 水セメント 比を65.0\%とした．使用材料については，セメントには 普通ポルトランドセメント, 細骨材には砕砂(化学法で 無害と判定), 粗骨材には砕石(化学法, モルタルバー法
ともに無害でないと判定)を使用した。また，ASRを促 すことを目的に $\mathrm{NaCl}$ 製造時に $18.9 \mathrm{~kg} / \mathrm{m}^{3}\left(\mathrm{Na}_{2} \mathrm{O}\right.$ 当量で $\left.10 \mathrm{~kg} / \mathrm{m}^{3}\right)$ を外割で添加した．なお，本実験で使用するコ ンクリートと同一材料・配合により作製した $\phi 100 \mathrm{~mm} \times$ 200mmの円柱供試体の3本について, デンマーク法によ る膨張量試験を実施した結果，促進後3か月で膨張量が

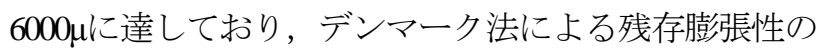
判断基準とされる4000ルに比して大きな膨張量であるこ

表-1 実験条件

\begin{tabular}{|c|c|c|c|c|}
\hline \multirow{2}{*}{$\begin{array}{c}\text { 供試 } \\
\text { 体 }\end{array}$} & \multicolumn{2}{|c|}{ ASR 促進 } & \multicolumn{2}{|c|}{ 輪荷重走行試験 } \\
\hline & $\begin{array}{c}\text { 急速試験 } \\
\text { Rapidly }\end{array}$ & $\begin{array}{c}\text { 緩速試験 } \\
\text { Slowly }\end{array}$ & $\begin{array}{c}\text { 乾燥 } \\
\text { dry }\end{array}$ & $\begin{array}{c}\text { 水張り } \\
\text { water }\end{array}$ \\
\hline N-d & $\times$ & $x$ & O & $\times$ \\
\hline R-d & $\bigcirc$ & $x$ & 0 & $x$ \\
\hline $\mathrm{R}-\mathrm{w}$ & $\bigcirc$ & $x$ & $x$ & $\bigcirc$ \\
\hline S-w & $x$ & $\bigcirc$ & $x$ & $\bigcirc$ \\
\hline
\end{tabular}

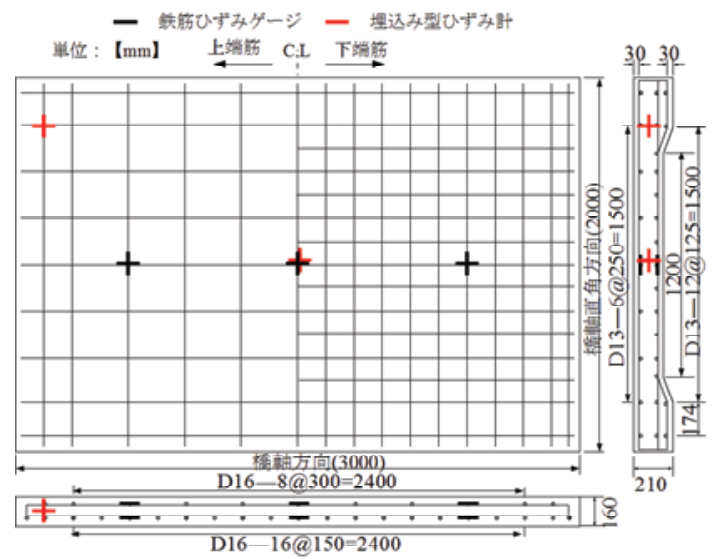

図-1 供試体概要

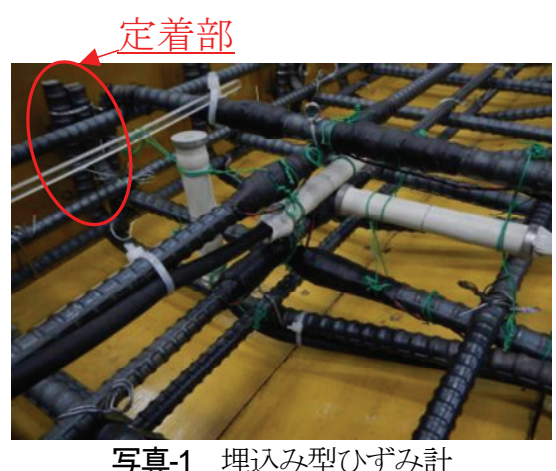

表-2 コンクリートの示方配合

\begin{tabular}{|c|c|c|c|c|c|c|c|c|c|c|c|c|}
\hline \multirow{3}{*}{$\begin{array}{c}\text { 粗骨材の } \\
\text { 最大寸法 } \\
\text { (mm) }\end{array}$} & \multirow{3}{*}{$\begin{array}{l}\text { スランプ } \\
\text { (cm) }\end{array}$} & \multirow{3}{*}{$\begin{array}{l}\text { W/C } \\
(\%)\end{array}$} & \multirow{3}{*}{$\begin{array}{l}\text { s/a } \\
\text { (\%) }\end{array}$} & \multirow{3}{*}{$\begin{array}{c}\text { 空気量 } \\
\text { (\%) }\end{array}$} & & & & & & & & \multirow{3}{*}{$\begin{array}{l}\mathrm{NaCl} \\
\left(\mathrm{kg} / \mathrm{m}^{3}\right)\end{array}$} \\
\hline & & & & & \multicolumn{5}{|c|}{ 単位量(kg/m³) } & \multicolumn{2}{|c|}{ 混和剤 } & \\
\hline & & & & & W & C & S1 & S2 & G & $\begin{array}{c}\mathrm{AE} \text { 減水剤 } \\
(\mathrm{C} \times \%)\end{array}$ & $\begin{array}{l}\text { 消泡剤 } \\
(\mathrm{C} \times \%)\end{array}$ & \\
\hline 20 & 12.0 & 65.0 & 45.0 & 4.5 & 175 & 269 & 413 & 405 & 1032 & 1.5 & 0.006 & 18.9 \\
\hline
\end{tabular}

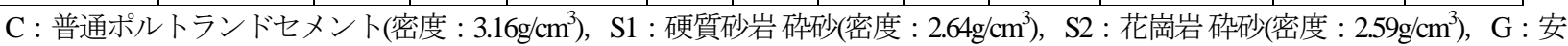
山岩砕石(密度 : $2.70 \mathrm{~g} / \mathrm{cm}^{3}$ ) 
とを確認している277.

各床版の材齢28日まで標準養生を行った $\phi$ $100 \mathrm{~mm} \times 200 \mathrm{~mm}$ のテストピースにおける圧縮強度とヤン グ係数は，N-dで圧縮強度 $22.8 \mathrm{MPa}$ ，ヤング係数 $28.0 \mathrm{GPa}$, R-dおよびR-wで圧縮強度 27.4MPa，ヤング係数 28.5GPa, S-wでは圧縮強度 $25.1 \mathrm{MPa}$ ，ヤング係数29.6GPa と，バッ チ間による差が生じたものの，いずれも設計基準強度 18MPaを満足する結果を示した.

表-3に，使用した鉄筋の物性を示寸．使用鉄筋は，全 供試体共通でSD295Aを使用し，主鉄筋(D16)は降伏強度 が358MPa，引張強度が527MPaであり，配力鉄筋(D13)は 降伏強度が338MPa，引張強度が488MPaであった。

\section{(3) 実験概要}

\section{a) ASR促進期間およびASR促進試験方法}

本研究では前述の通り，ASRがRC床版の而疲労性に 及ぼす影響について検討するため，環境条件の異なる2 条件の促進試験を行った．まず，急速試験では，大型の 環境試験装置(写真-2) を用いて，槽内温度 $50^{\circ} \mathrm{C}$ ，相対湿 度80\%の一定環境下において飽和 $\mathrm{NaCl}$ 水溶液を床版上面 に湛水させることで実施した (写真-3) 。 なお，床版上面 以外の5面には防水シートを貼付し，塩化物イオンの供 給を床版上面に限定した ${ }^{28)}$ 。また，圧縮強度試験に用い る円柱供試体については，同温湿度環境下での封かん養 生とした。次に，緩速試験では，実験が長期に渡ること を想定し，ASRを緩やかに促進させつつ鉄筋の腐食を抑 制するため, 福島県郡山市の日本大学構内にある水槽を 用いて，5\% $\mathrm{NaCl}$ 水溶液中に供試体を浸漬させた (写真4)。緩速試験の際，圧縮強度試験用供試体は，側面に養 生シートを貼付し， $5 \% \mathrm{NaCl}$ 水溶液中に浸漬させた。

なお，各養生期間途中でのASRによる床版の劣化度は， 鉄筋およびコンクリートの膨張ひずみの計測と，床版上 面に発生するひび割れの観察により判定した.

\section{b) 各床版のASR促進および養生期間}

図-2に実験経過を示す。ここで，本実験のASR促進試 験および輪荷重走行試験，各種養生の期間は，後述する ASRによるコンクリートの膨張量，および輪荷重走行試 験装置の載荷試験工程より決定した。図より，N-dでは 材齢28日まで湿布養生を行い，その後，輪荷重走行試験 を実施した．次に，R-dでは，28日間の湿布養生後，促 進を41日間行った。 その後, 輪荷重走行試験準備期間に おいて鉄筋腐食を抑制する措置として，真水湛水養生お よび湿布養生を27日間行い，輪荷重走行試験を実施した。 R-wでは，材齢9日までの湿布養生後，R-dの急速試験が 終了するまでの期間中において緩速試験を実施すること で，鉄筋腐食を抑制させつつ緩やかにASRを促進させた。 その後, 後述するASRによるコンクリートの膨張が比較
表-3 鉄筋の物性

\begin{tabular}{|c|c|c|c|c|}
\hline 使用鉄筋 & $\begin{array}{c}\text { 降伏 } \\
\text { 強度 } \\
(\mathrm{MPa})\end{array}$ & $\begin{array}{c}\text { 引張 } \\
\text { 強度 } \\
(\mathrm{MPa})\end{array}$ & $\begin{array}{c}\text { ヤング係 } \\
\text { 数 } \\
(\mathrm{GPa})\end{array}$ & $\begin{array}{c}\text { 降伏 } \\
\text { ひずみ } \\
(\mu)\end{array}$ \\
\hline $\begin{array}{c}\text { 主鉄筋 } \\
(\mathrm{D} 16)\end{array}$ & 358 & 527 & 198 & 1835 \\
\hline $\begin{array}{c}\text { 配力鉄筋 } \\
(\mathrm{D} 13)\end{array}$ & 338 & 488 & 193 & 1826 \\
\hline
\end{tabular}

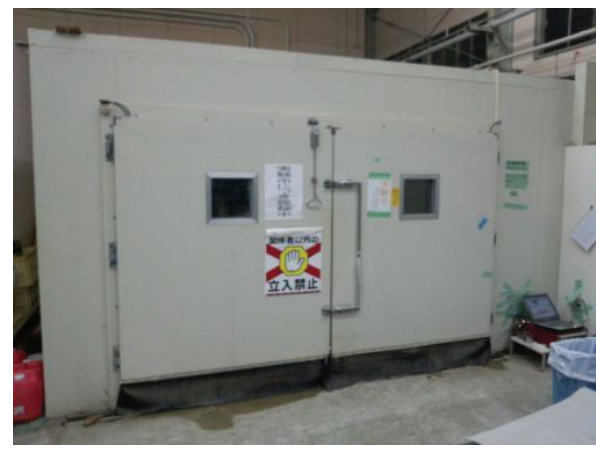

写真-2 大型環境試験装置

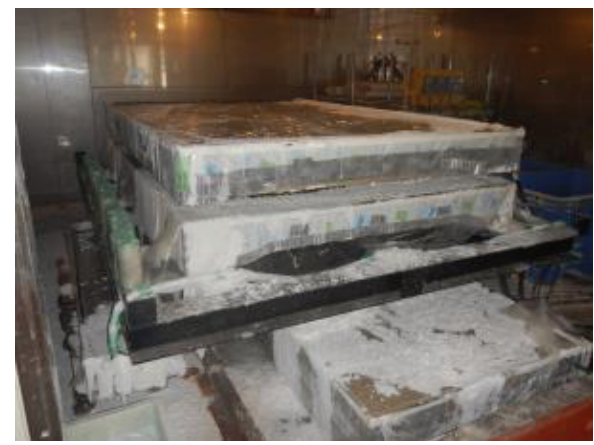

写真-3 急速試験状況

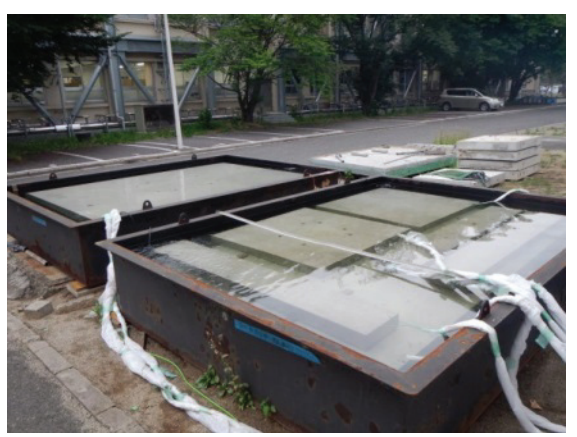

写真-4 緩速試験状況

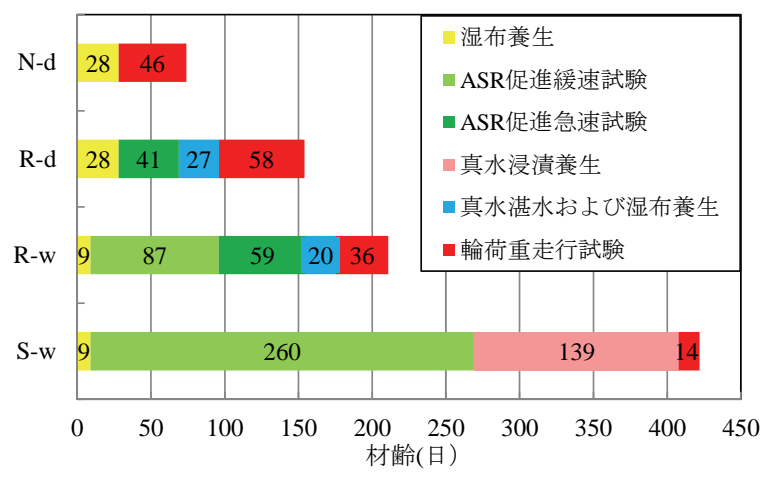

図-2 実験経過 
的小さな段階で急速試験に移行した．また．急速試験は， R-dよりも18日長い59日間行い，20日間の真水湛水養生 および湿布養生後, 輪荷重走行試験を実施した. S-wで は，9日間の湿布養生後，260日間の緩速試験を実施し た. なお，S-wでは，後述するコンクリートおよび鉄筋 のひずみ増加量がR-dおよびR-wよりも緩慢であり，ひ ずみを統一寸るには，実験が大幅に長期化するため，床 版上面におけるひび割れの発生状況が目視上でR-d, R$\mathrm{w}$ と同程度となった段階で緩速試験を終了した. その後, 輪荷重走行試験を開始するまで待機期間が生じたため, 139日間真水に浸漬させることでASRの発生および鉄筋 の腐食を可能な限り抑制した。

\section{c) 輪荷重走行試験概要}

本研究では, RC床版に疲労損傷を与える手段として, 輪荷重走行試験を行った.

写真-5に輪荷重走行試験装置を示す，走行試験は，鋼 製フレームに鉄車輪を取り付けた油圧ジャッキを据え付 け，回転速度8.97pmのモータおよびクランクアームで 供試体を載せた台車を前後に $1 \mathrm{~m}$ 往復運動させる機構で 実施した.

輪荷重走行試験における供試体の支持条件を図-3に示 す. 供試体の支持条件は既往の研究29)を参考にし, 長辺 方向の 2 辺は台車支持桁への固定はせず，丸鋼による単 純支持とし鉛直方向の変位のみを拘束した. また，短辺 方向の2辺は実橋の連続性の再現を考慮して, 端析によ る弾性支持とし，変位を拘束することで短辺からの曲げ 破壊を防止した。 また，荷重載荷時に発生寸る床版四隅 の浮上りを防止するため, $\mathrm{PC}$ 鋼棒により床版を台車支 持析に固定した.

水張り範囲(図-3中の水張り枠内)は, L $\mathrm{L}$ 型アルミ鋼材を 用いて，輪荷重軌道部を中心に長さ2200mm，幅 $1500 \mathrm{~mm}$ の土手を作製し, 漏水防止のため, 水張り枠にシリコン を注入した. その後, 水張り範囲内に養生シートを敷き 詰め, その上から散水を行った. なお, 輪荷重走行試験 途中において, 水が床版上面より常時5 mmを保つように 留意した.

輪荷重走行試験における載荷ステップは，T荷重にお ける1車輪分の荷重である98kN(10tf)を基本荷重とし, 走 行回数が 10 万回, 20 万回, 25 万回に達した際に, 載荷荷 重を29.4kNずつ増加させる段階載荷方式により実施した。

計測項目は，図-4に示すように，目標走行回数終了時 点で基本荷重 $98 \mathrm{kN}$ 供試体中央に静的載荷した際の床 版に発生する活荷重たわみ(弾性変形成分のたわみ)の計 測と供試体下面のひび割れ観察である. なお, 活荷重た わみの計測には高感度変位計(感度 $1 / 100 \mathrm{~mm})$ を用い, 供 試体中央に加え, 供試体中央から橋軸方向, 橋軸直角方 向にそれぞれ200mmずつ配置した．また，ひび割れ密度

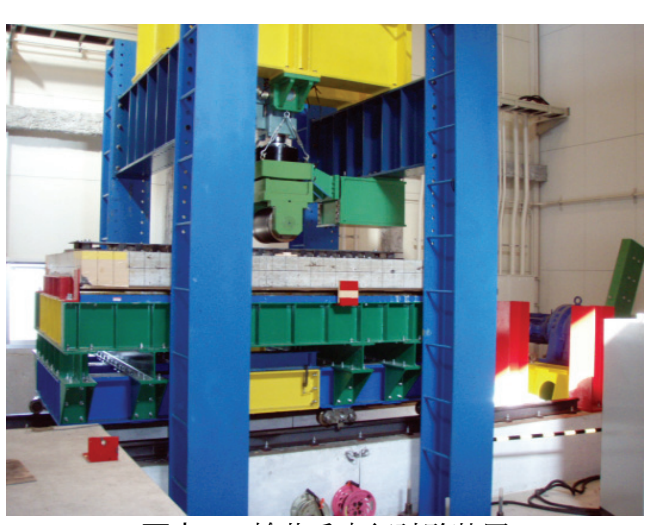

写真-5 輪荷重走行試験装置

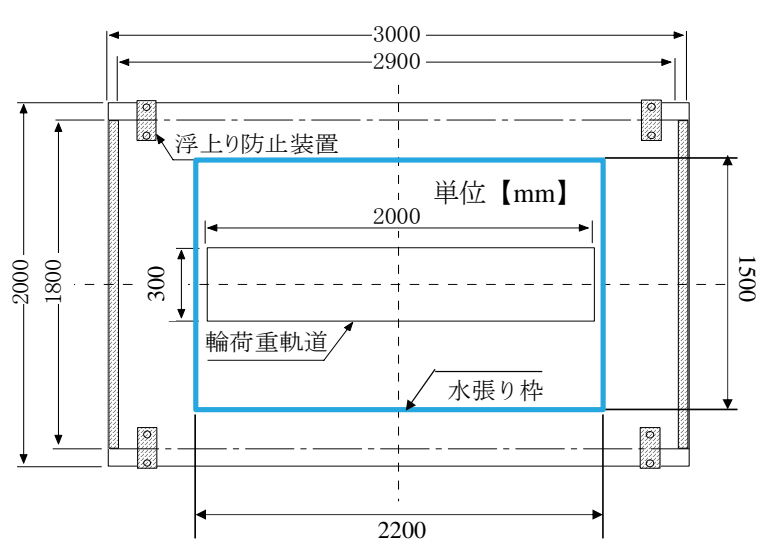

図-3 床版の支持条件

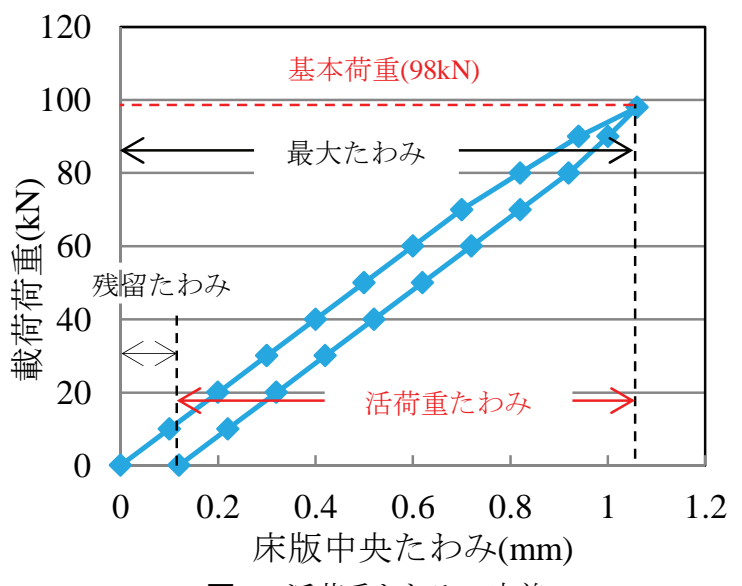

図-4 活荷重たわみの定義

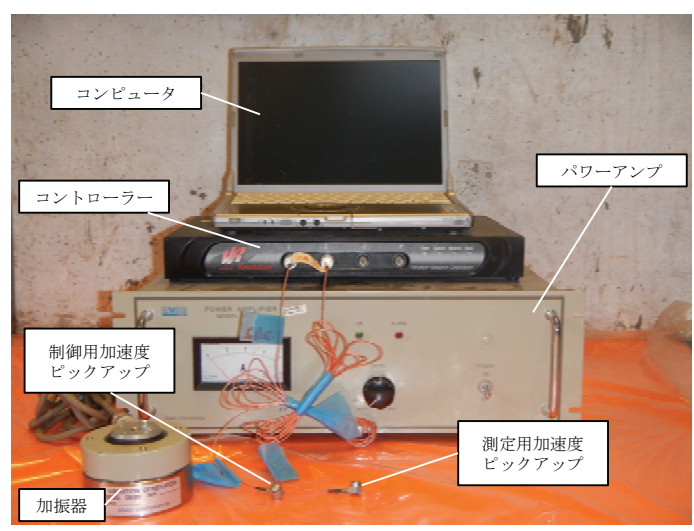

写真-6 小型加振器 
は，供試体下面のひび割れをスケッチし，パソコン上で これをトレースした後, 画像解析ソフトによって床版中 央の $1600 \mathrm{~mm} \times 1200 \mathrm{~mm}$ 範囲にあるひび割れの総延長を 求め算出した.

輪荷重走行回数は，段階載荷による走行回数を $98 \mathrm{kN}$ による走行回数に換算した等価繰返し走行回数で評価し た. 具体的には，各荷重における走行実績を，マイナー 則を仮定した式(1)により 98kNに換算した際の走行回数 として求めた ${ }^{30}$.

$$
N_{e q}=\sum\left(P_{i} / P_{0}\right)^{m} n_{i}
$$

ここで, $N_{e q}$ : 基本荷重 $P_{0}$ に換算した走行回数, $P_{0}$ : 基 本荷重 $(98 \mathrm{kN}), n_{i}$ : 荷重 $P_{i}$ の走行回数, $m: \mathrm{S}-\mathrm{N}$ 曲線の傾 きの逆数(12.76)である ${ }^{31}$.

\section{d) 強制振動試験}

本研究では, ASR によるコンクリート内部の損傷度 を定量的に評価するため，著者らがこれまでに開発して きた非破壊検査手法である，100～20,000Hz までの調和 振動が与えられる電磁コイル式の小型加振器を励振器と した強制振動試験を実施した ${ }^{32}$-34. 本手法は，調和振 動を与えることにより加振方向の縦振動を励起させ，振 動が及ぶ範囲の共振周波数を測定するものである.さら に，モード解析と同様に，ひび割れや空隙によって剛性 と共振周波数が低下寸ることに着目して，部材内部の劣

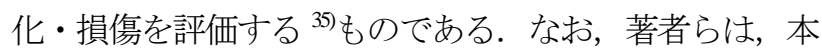
手法による床版の損傷度評価が，床版下面からの観察で は検知が困難な床版内部の劣化程度を評価可能であるこ とを示している ${ }^{30}$.

本実験での強制振動試験に用いた電磁コイル式の小型 加振器を写真-6 に示寸. 本実験で使用した小型加振器 は, 寸法 $\phi 95 \mathrm{~mm} \times 56 \mathrm{~mm}$, 重さ $1.8 \mathrm{~kg}$, 最大加振力 $50 \mathrm{~N}$, 可 変周波数 100 20,000 Hz である. 試験方法は，小型加振 器の振動面に貼付した制御加速度ピックアップの值をデ ジタル振動制御装置に取り込み，これが事前にプログラ ムした加速度パターンと合致するようにパワーアンプか ら小型加振器に送る電流量をコンピュータで制御する. このとき, 小型加振器周辺で床版に貼付した測定用加速 度ピックアップにより応答加速度を測定し, 図-5 に示 すような共振曲線を得る。

振動試験は, 加振器の振動テーブルを床版に当て, 鈆直方向 (床版厚さ方向) に調和振動を与えた.このと き，加振器と床版の間に，緩衝材として段ボールを挟む ことで, 加振器本体から床版に伝わる振動を防いだ，そ して, 加振点付近に計測用加速度ピックアップを厚さ 0.6mm の両面テープを介して床版に接触させ，床版の定 常応答 (鉛直方向加速度)を測定した. これにより図-6に 示すように部材全体ではなく，局所的な損傷を評価する

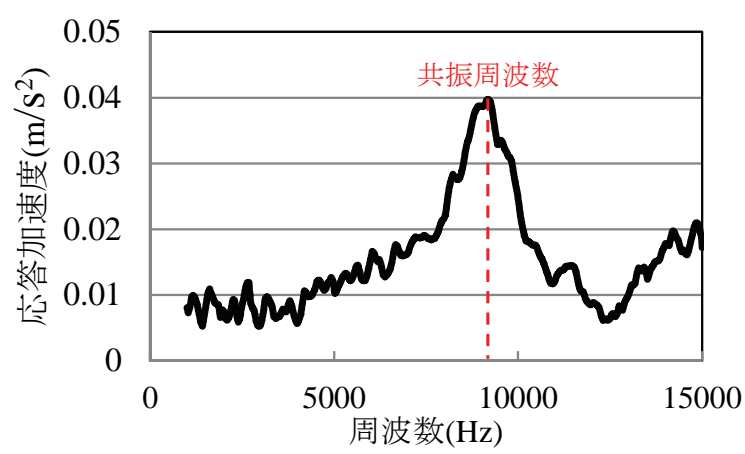

図-5 共振曲線の一例

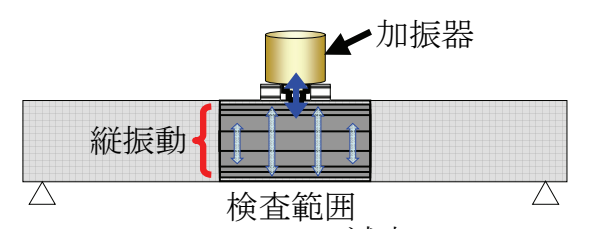

減衰

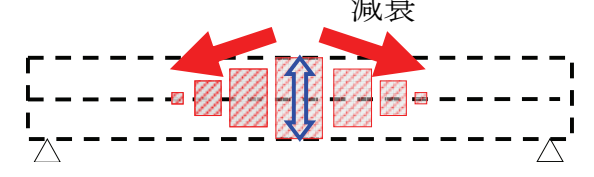

図-6 周波数測定概略

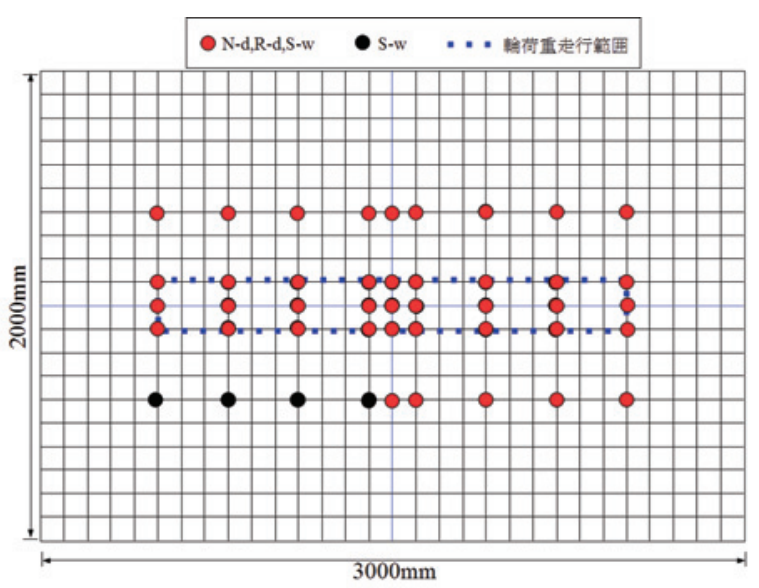

図-7 周波数測定位置

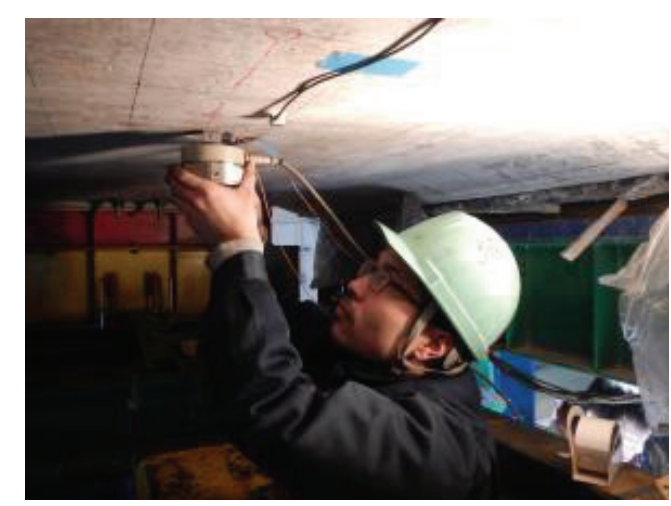

写真-7 測定状況

ことが可能であり，原理として上下面で同じ計測結果が 得られる. 今回の測定では, 掃引周波数を 1,000 $15,000 \mathrm{~Hz}$, 加振器の加速度振幅 $1.0 \mathrm{~m} / \mathrm{s}^{2}$, 測定時間 18 秒を基 本とした. 振動試験は，N-d では実走行回数 3 万回, 7 万 
回, 10 万回, 11.5 万回, 14 万回, 16 万回時の計 6 回, R-d で は実走行回数 0 回, 3.5 万回, 10 万回, 18 万回, 22 万回時の 計 5 回，S-w では，実走行回数 0 回，5 万回，10 万回， 押抜きせん断破壊後の計 4 回行った. なお，R-wでは， 実験の都合上，共振周波数の計測を実施していない.

小型加振器による共振周波数の測定位置を図-7 に示 す．測定は，300 $\mathrm{mm} \times 300 \mathrm{~mm}$ 範囲を基本とし，輪荷重 走行位置に関してはより密に計測を行った。測定点は N-d，R-d で 41 箇所，S-w で 45箇所である. RC床版供試 体の測定状況を写真-7 に示す. 共振周波数の測定は, N-d および R-d では床版上面で行い，水張りを行った Swでは床版下面で実施した.

\section{e) 実体顕微鏡によるASRの発生状況の確認}

本実験では，床版コンクリートにおけるASRの発生有 無を確認するため, 実体顕微鏡を用いて反応リムの発生 および，それに伴う微細なひび割れの観察を実施した。 具体的には，輪荷重走行試験後に疲労破壊の影響を受け ていない範囲で，床版上面から床版厚さ方向に $\phi 100 \mathrm{~mm}$ で採取したコア(以下，採取コア)をディスク状に切り出 し，その切断面を肉眼および実体顕微鏡で観察した。

\section{f) ASRによる床版内部のひび割れ発生状況観察}

本実験では，ASRにより発生した床版内部のひび割れ を観察するため, 採取コアを石膏で整形加工後, コンク リートカッターで2分割し，蛍光塗料(シアノアクリレー 卜性)をコンクリート表面に刷毛で満遍なく塗布させる ことで浸透させた. その後, 暗室内でブラックライトを 当ててコア断面を観察した.

\section{g）供試体断面損傷状況の観察}

本研究では, 輪荷重走行試験における供試体の損傷状 況を確認するため, 輪荷重走行試験終了後に4分割した 中央断面における破壊状況の観察を写真およびスケッチ により行った.

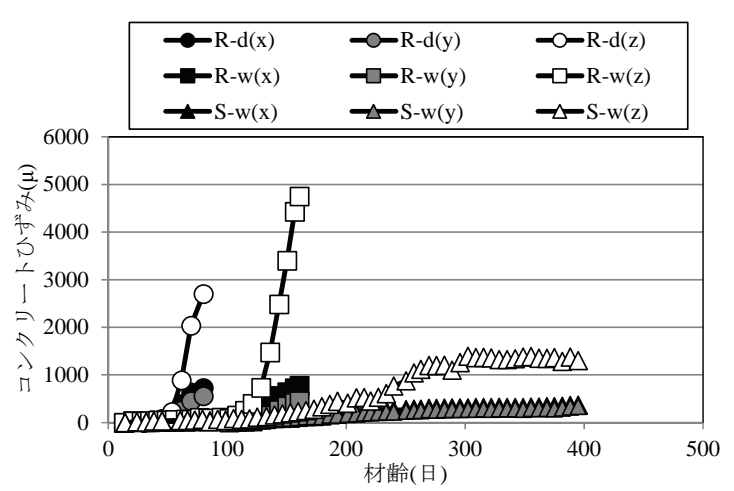

図-8 コンクリートのひずみ変化(床版中央部)

\section{ASR促進によるRC床版の劣化状況}

\section{(1) ASRによる床版コンクリートのひずみ変化}

図-8および図-9に，ASR促進による床版コンクリート のひずみ変化量を示す。なお, 前述の通り, S-wについ ては床版端部にひずみ計を設置していない. 図-8より, 床版中央部のひずみは，床版を問わず鉄筋に拘束される $\mathrm{x}$ 方向とy方向で同じような膨張挙動を示す一方で, $\mathrm{z}$ 万 向では明らかに膨張量が増加する傾向を示した。これは， ASRによるコンクリートの膨張が鉄筋の拘束を受けにく い方向に進展したためと考えられる. また，急速試験に よりASRを促進させたR-d，R-wではz方向の膨張量が急 激に立ち上がる傾向を示しているのに対して，S-wでは 比較的緩やかに膨張する傾向を示しており，環境条件の 異なるASR促進試験を実施することでコンクリートの膨 張速度に差が生じる結果となった。 なお，促進試験の ASR促進終了時におけるひずみは，急速試験を行った床

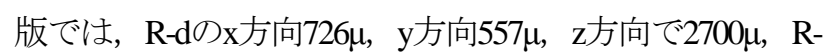

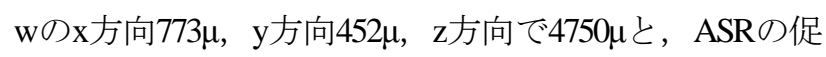

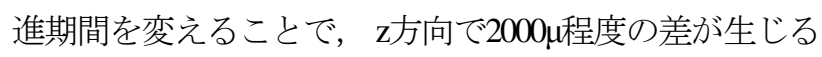
結果となった. 一方で, S-wではx方向 $365 \mu, \mathrm{y}$ 方向 $334 \mu$, z方向で1302 $\mu$ と, 最も小さい膨張量を示した.

図-8および図-9より，床版中央部と床版端部のひずみ は，x方向およびy方向では同様の膨張傾向を示した。一 方， $\mathrm{z}$ 方向の膨張量については，床版端部でひずみが小 さい結果を示した.これは, 写真-1に示すように, 定着 確保のために床版端部で鉄筋厚さ方向の鉄筋が配置され ていることから， $\mathrm{z}$ 方向の膨張を拘束したものと推察さ れる.このように，ASRによるコンクリートのひずみは， 鉄筋に拘束されるxおよびy方向では床版端部と床版中央 で大きな差はないが，z方向については床版端部よりも 床版中央でひずみが大きくなる傾向を示した.

\section{(2) ASRIによる鉄筋のひずみ変化}

図-10に，ASR促進による床版内部の鉄筋ひずみ変化 量の一例として，床版中央位置における主鉄筋のひずみ

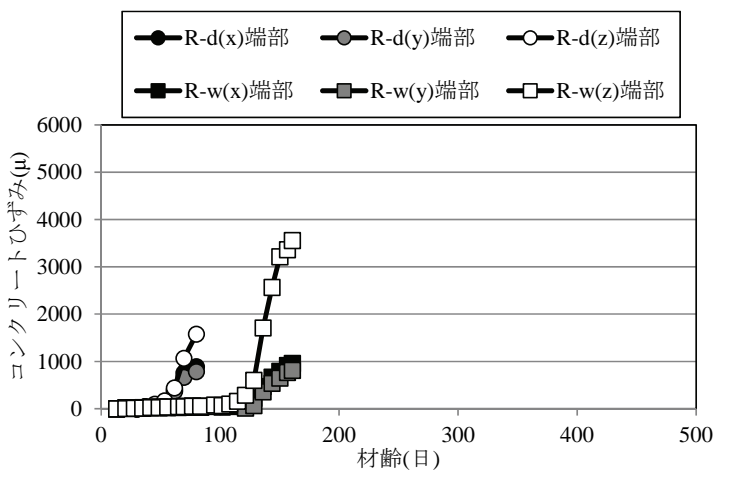

図-9 コンクリートのひずみ変化(床版端部) 
変化量を示す，図より，鉄筋ひずみは，コンクリートの 膨張量同様に，急速試験を行ったR-d，R-wではひずみ が急激に立ち上がる傾向を示し，緩速試験を行ったS-W では，緩やかな変化を示した。

図-11に，ASR促進終了時における主鉄筋のひずみ分 布を示す. 図より，いずれの床版についても, コンクリ 一トのz方向におけるひずみ変化と同様に，上下鉄筋と もに床版中央部で最も大きなひずみを示した．また，各 床版での中央部と端部でのひずみの差異については, 概 ね同程度であった，各床版のひずみを比較すると，急速 試験を実施したR-w，S-wでは同程度であるのに対し， 緩速試験を実施したS-wでは，いずれの鉄筋位置におい ても最も小さいひずみを示した.このように鉄筋ひずみ は，コンクリートのひずみ変化と同様に中央よりも供試 体端部付近の方がひずみは小さく，また極端なx方向お よびy方向の両者のひずみの相違は認められなかった. すなわち，このひずタ計測から促進方法の違いによる3 方向のASRの膨張を概社把握できたと考えられる.

\section{(3) 床版に導入されるケミカルプレストレス}

表-4および表-5に，各床版の中央位置における鉄筋の ひずみとケミカルプレストレスを示寸. なお，ケミカル プレストレスは，膨張エネルギー一定則を参考とした ASRが生じたRC部材のケミカルプレストレスの算出式 である式(2)より算出した ${ }^{11)}$.

$$
\sigma_{c p}=p \times E_{\mathrm{s}} \times \varepsilon_{c p}
$$

ここで, $\sigma_{q}:$ 導入されるケミカルプレストレス, $p:$ 拘束鋼材比 $\left(=A_{s} / A_{c}\right), E_{s}$ : 鋼材のヤング係数, $\varepsilon_{p}$ : 鋼材 に生じるひずみ, $A_{s}$ : 鉄筋の総断面積, $A_{c}$ : コンクリー トの断面積である.

表より，主鉄筋のひずみはいずれの床版においても下 側よりも上側で大きく，鉄筋のひずみの差により床版上 面が凸に反るような変形が生じたものと考えられる．ま た，各床版の鉄筋ひずみおよびケミカルプレストレスは， 急速試験を行ったR-dとR-wでは，鉄筋間でのバラつき はあるものの, ケミカルプレストレスの平均值は同程度 であったのに対し，緩速試験を実施したS-wではその半 分程度であった。

\section{（4）ASRIよるコンクリートの劣化評価}

図-12に，輪荷重走行試験開始時材齢における压縮強 度試験用供試体および採取コアによる圧縮強度とヤング 係数の関係を示す，なお，図中には圧縮強度とヤング係 数の設計用值 ${ }^{37}$ を併せて示した. ここで，採取コアにつ いては，膨張量を計測している位置で採取するのが望ま しいが，ASRによるコンクリートの劣化を評価する上で,

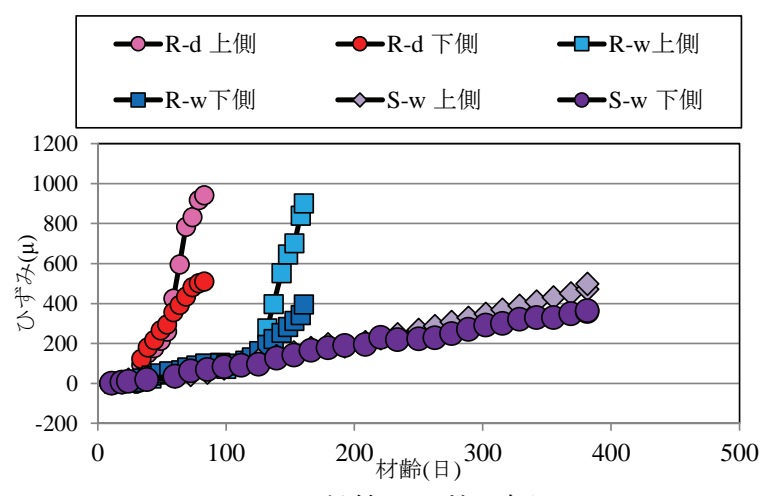

図-10 鉄筋のひずみ変化

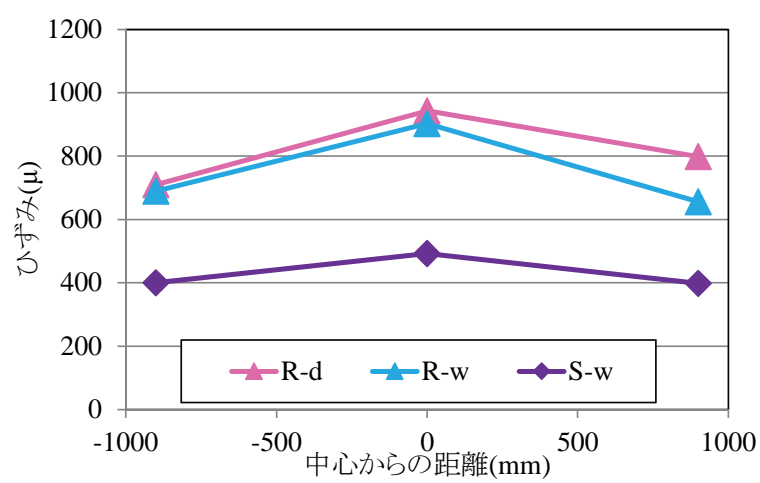

(a) 上側主鉄筋

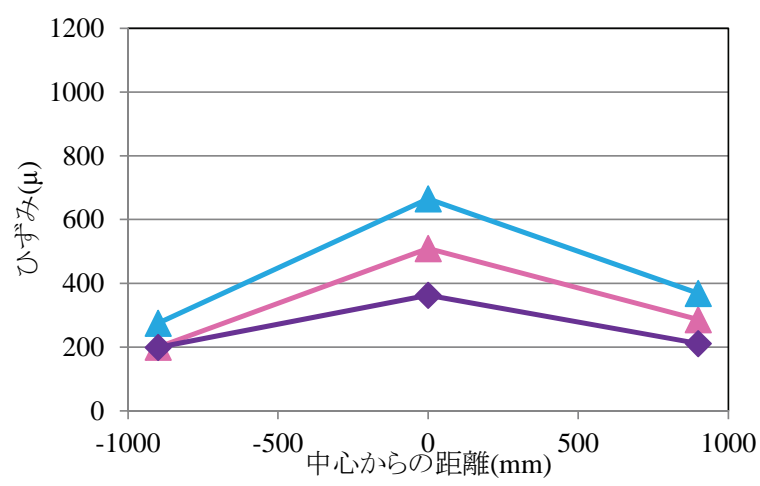

(b) 下側主鉄筋

図-11 主鉄筋のひずみ分布

表-4 鉄筋のひずみ

\begin{tabular}{|c|c|c|c|c|}
\hline \multirow{2}{*}{ 供試体 } & \multicolumn{4}{|c|}{ ひずみ $(\mu)$} \\
\cline { 2 - 5 } & \multicolumn{2}{|c|}{ 主鉄筋 } & \multicolumn{2}{|c|}{ 配力鉄筋 } \\
\cline { 2 - 5 } & 上側 & 下側 & 上側 & 下側 \\
\hline R-d & 942 & 510 & 1036 & 793 \\
\hline R-w & 902 & 665 & 681 & 858 \\
\hline S-w & 492 & 362 & 356 & 515 \\
\hline
\end{tabular}

表-5 ケミカルプレストレス

\begin{tabular}{|c|c|c|}
\hline \multirow{2}{*}{ 供試体 } & \multicolumn{2}{|c|}{ ケミカルプレストレス $(\mathrm{MPa})$} \\
\cline { 2 - 3 } & 主鉄筫方向 & 配力鉄筋方向 \\
\hline R-d & 1.9 & 2.4 \\
\hline R-w & 2.1 & 2.0 \\
\hline S-w & 1.1 & 1.1 \\
\hline
\end{tabular}


疲労破壊の影響を受けていない範囲でのみコアを採取し た.また，コアは後述する図-14に示す位置で床版厚さ 方向に $\phi 100 \mathrm{~mm}$ で採取した. なお，本実験に使用した採 取コアは， $\phi 100 \mathrm{~mm}$, 高さ160mmと，JS A 1149 「コンク リートの静弾性係数試験方法」によって定められる供試 体寸法の条件を満たしていないため参考值とし, 図中に は高さ直径比が2.0の強度に補正した結果を示している.

図より，各床版の試験開始時における圧縮強度試験用 供試体(凡例にTPと表記)の圧縮強度は，促進試験を行っ ていないN-d(材齢34日)で圧縮強度25.5MPa，ヤング係数 26.3GPa，急速試験を実施したR-d(材齢97日)で圧縮強度 34.3MPa，ヤング係数27.1GPa，R-w(材齢177日)で34.6MPa, ヤング係数25.3GPaであった．ASR促進を実施したR-dお よびR-wの圧縮強度試験用供試体では，設計用值よりも 若干ヤング係数が低い值を示したが，これは封かん養生 ではあるものの，促進期間においてASRが多少進行した 影響であると考えられる. 一方で，緩速試験を実施した S-wでは圧縮強度24.6MPa，ヤング係数10.6GPa と圧縮強 度，ヤング係数ともに設計用值よりも大きく低下する結 果を示した. これは，促進期間においてASRが進行した ことで，コンクリートの物性が大きく低下したためと推 察される ${ }^{11)}$. 次に，採取コアでは，N-dよりも，ASR促 進を実施したR-d，R-w，S-wで圧縮強度およびヤング係 数の低下が著しい結果を得た。特に，R-dおよびR-wに ついては, 圧縮強度, ヤング係数ともにTPよりも大き く低下する結果であった。これは前述の通り，ASR促進 試験中における塩分および水分の供給条件が異なったこ とで, ASRの劣化程度に差異が生じたことに起因すると
考えられる. それぞれの床版における採取コアの試験結 果と設計用值と比較してみると, 圧縮強度に対するヤン グ係数が大きく低下したことがわかる，これは，ASRに より床版内部にひび割れが生じたことによるものだと推 察され，いずれの床版についてもASRによってコンクリ 一ト内部の劣化が進行したと判断される.

\section{(5) ASRIよるひび割れおよびASRゲルの発生状況}

図-13および図-14に，ASR促進後に観察した，床版上 面と下面のひび割れ発生状況を示す.なお，眓中の水色 で示される箇所は，前述したコアの採取位置を示してい る. 図よりいずれの床版においても，床版上面と下面で は，上面でひび割れが多く発生した．床版上面からのみ 塩分を供給したR-d, R-wのみならず，床版全面から塩 分が供給されるS-wについても同様の傾向であつたこと を考えると, 床版上下面のひび割れ発生状況の違いは,

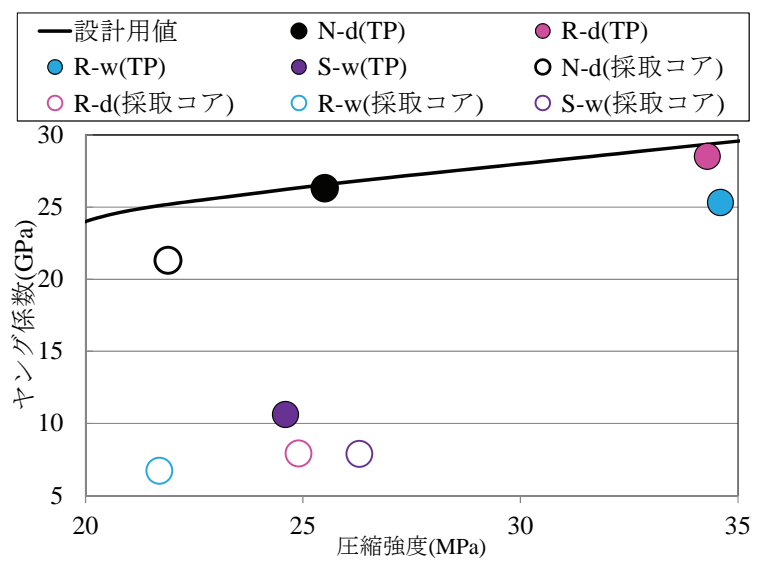

図-12 圧縮強度とヤング係数

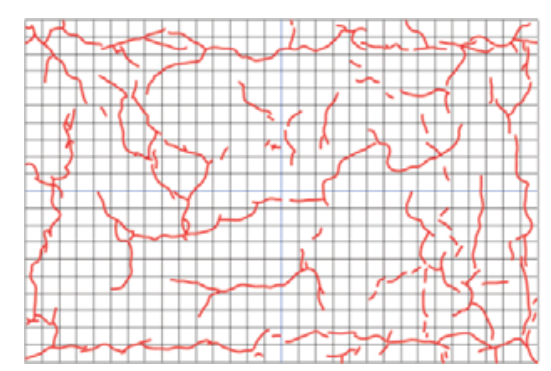

(a) R-d

(b) R-w

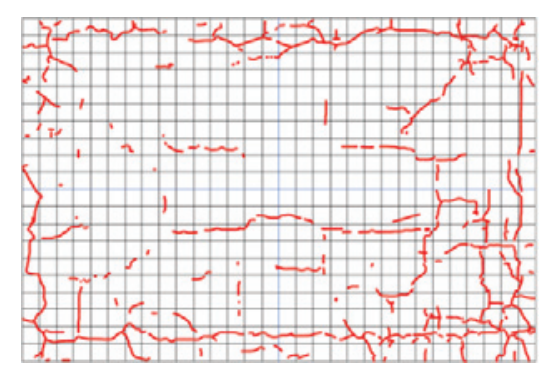

図-13 ASR促進後のひび割れ発生状況(床版上面)

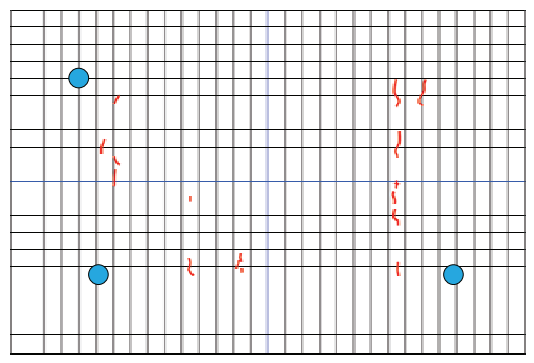

(a) R-d

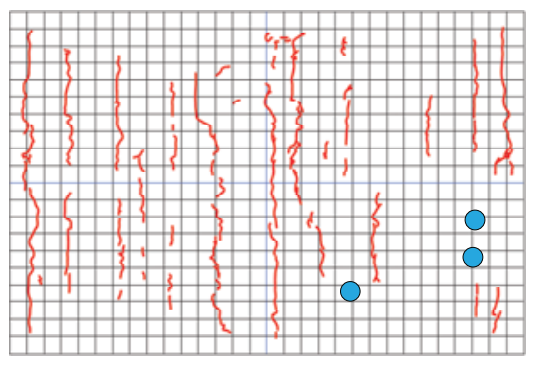

(b) R-w

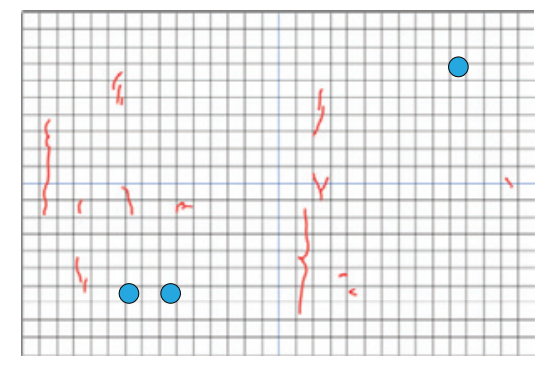

(c) S-W

図-14 ASR促進後のひひ割れ発生状況(床版下面) 


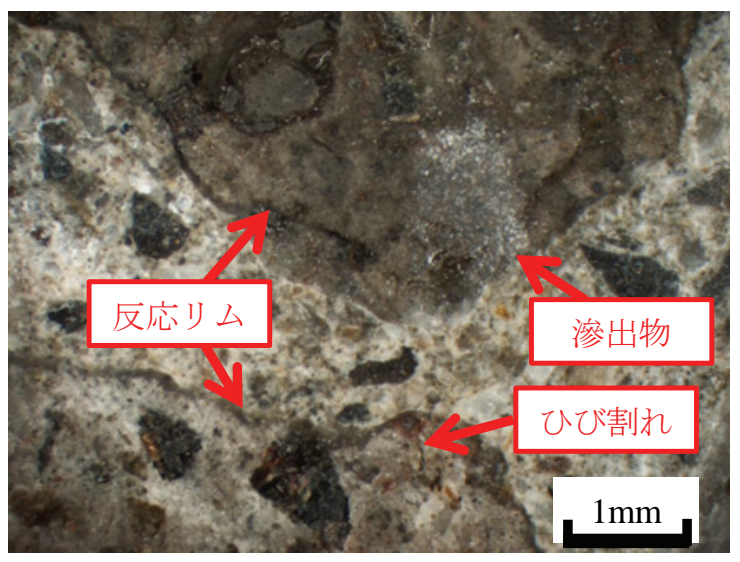

(a) R-d

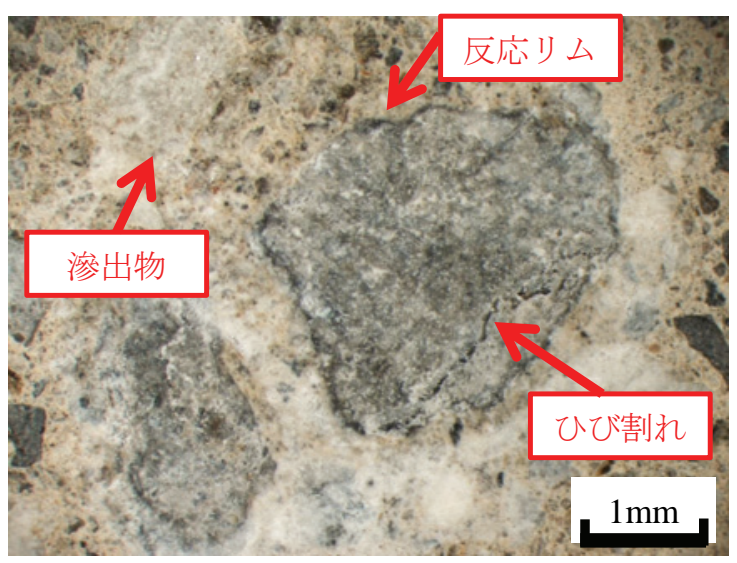

(b) S-W

写真-8＼cjkstart実体顕微鏡による ASR ゲルの観察

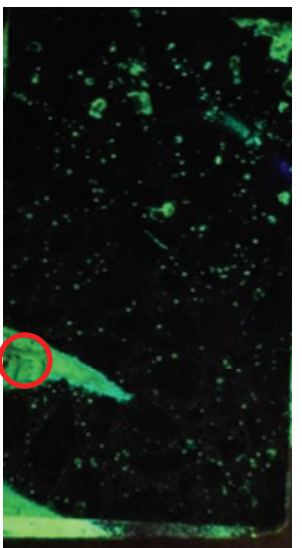

(a) N-d

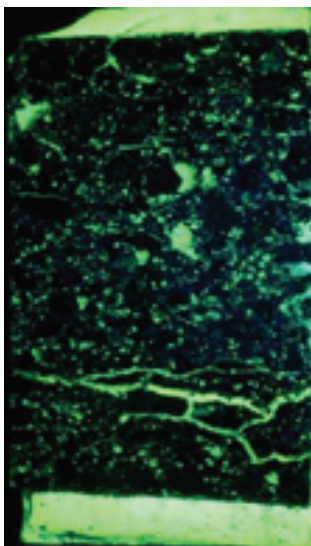

(b) R-d

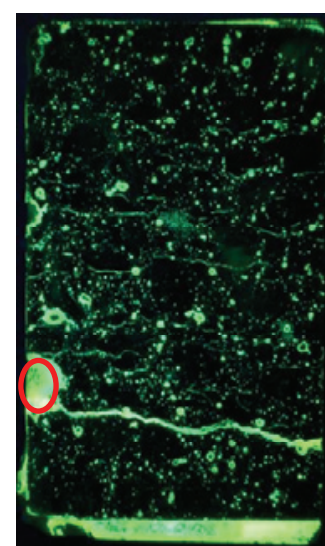

(c) $\mathrm{R}-\mathrm{w}$

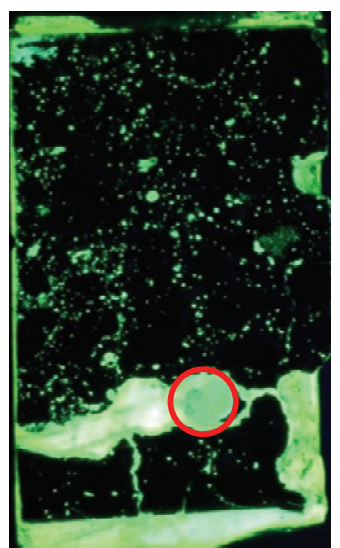

(d) S-W

写真-9 蛍光塗料によるひび割れの観察

鉄筋量の違いにより床版上面が凸に反るような変形が生 じ，床版上面で引張応力が大きくなったことなどに起因 すると考えられる．また，床版上面では，いずれの床版 についても供試体端部にひび割れが多くみられたが，こ れは，供試体端部と中央では配筋量に差があることで， 膨張に対する拘束度が異なったためと推察される。一方， 床版下面では, ひび割れの発生は上面に比して少なかっ た.また，ひび割れのほとんどが主鉄筋方向に生じてお り，これについては主鉄筋と配力鉄筋の配筋量の差によ ると考えられる.

各床版のASRによるひび割れはR-d，S-wよりもR-wで 多く発生する結果となった。これは, R-wではz方向に おけるコンクリートの膨張量が大きく，これに伴いひび 割れが多く生じたと考えられる. なお，各床版に生じた ひび割れの最大のひび割れ幅は，急速試験を行ったR-d では，上面で $0.1 \mathrm{~mm}$ ，下面で $0.05 \mathrm{~mm}$ ，同じく急速試験を 行ったR-wでは上面で0.05mm，下面で0.05mmであったの に対し, 緩速試験を実施したS-wは上面で $0.1 \mathrm{~mm}$, 下面 で0.3mmと, 最もひび割れ幅が大きい結果を示した.こ のように，ASR促進速度および促進期間を変えることで,
床版上面あるいは下面に発生するひび割れの発生形態が 大きく異なることが示された. これら促進速度の違いに よるひび割れ発生形態の差異については, ASR促進時に おけるASRゲルの生成や移動といった時間依存性のある 現象が影響している可能性 ${ }^{30)}$ が考えられるが，これにつ いては今後の検討課題としたい.

写真-8に，実体顕微鏡によって観察したASRの発生状 況の例として, R-wとS-wの観察結果を示す. 写真より, 本実験で使用した床版では，骨材粒子周辺のセメントペ 一ストに滲出物が認められ, ASRが発生していることが 確認された. また，骨材には反応リムおよびゲルによる と思われるひび割れの発生が認められ，ASRに起因した と思われるひび割れにより, 床版コンクリートの劣化が 進行していることが確認された.

写真-9に，床版内部に発生したひび割れの状況を示す。 なお，写真中の赤丸は鉄筋位置を示しており，白着色部 は整形時に使用した石膏である. 写真より，まずASR促 進を行っていないN-dについては, 目視上ではASRによ るひび割れは確認されなかった。一方で，ASR促進を実 施した床版では，いずれもASRによる劣化を生じた実床 
版で見られるような水平方向のひび割れが15観察された. 特に, 急速試験を行ったR-dおよびR-wでは, 水平方向 のひび割れが多く見られ，ASRによる床版内部の劣化が 確認された．また， R-wではR-dよりもひび割れの本数 が多く発生しているが，これは，床版汸向におけるコ ンクリートの膨張量の差が要因と判断される. 一方で, 緩速試験を実施したS-wでは, 目視で観察できるひび割 れはR-dおよびR-wに比して少なく, ASRによるひび割 れの発生は顕著でなかった。 しかし, 実体顕微鏡によ る観察ではASRに起因すると思われる微細なひび割れが 観察されており，骨材周辺や骨材を横断するような微 細なひび割れが多数生じていた可能性が考えられる.

このような, 各床版での微細なひび割れの発生機構に ついては今後さらに究明する必要がある.

\section{（6）鉄筋腐食減量率の測定結果}

本実験では，ASR促進時において高濃度の塩分を床版 に供給していることから，鉄筋の腐食状況を定量的に 評価する必要があると判断し，輪荷重走行試験後に鉄 笳腐食減量試験を実施した.

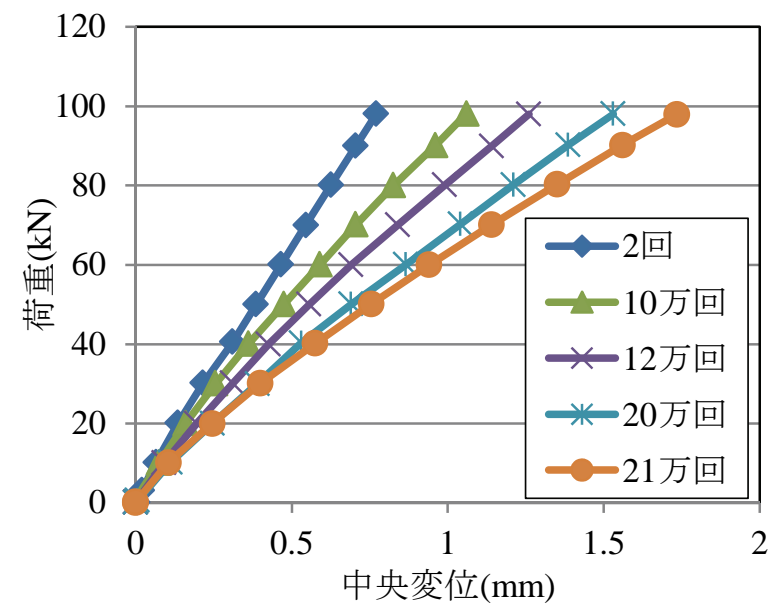

(a) N-d

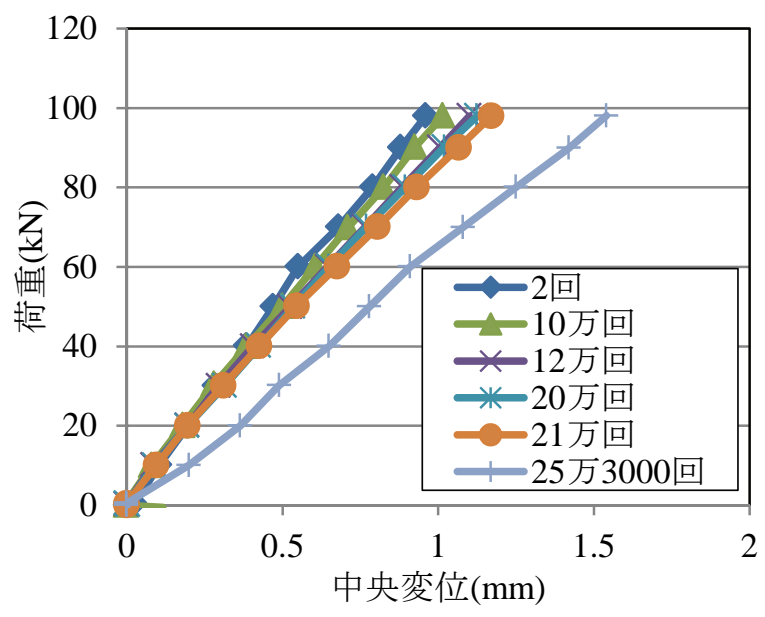

(c) $\mathrm{R}-\mathrm{w}$
試験に用いた鉄筋は，輪荷重走行範囲外の位置で鉄筋 をはつり出し，上下主鉄筋，上下配力鉄筋を各床版から 1本ずつ採取した。 その結果, 鉄筋腐食減量率はいずれ の床版についても1.0\%以下であり，本実験の範囲内では 塩害がRC床版の而疲労性に与える影響は軽微であると 判断した ${ }^{8)}$.

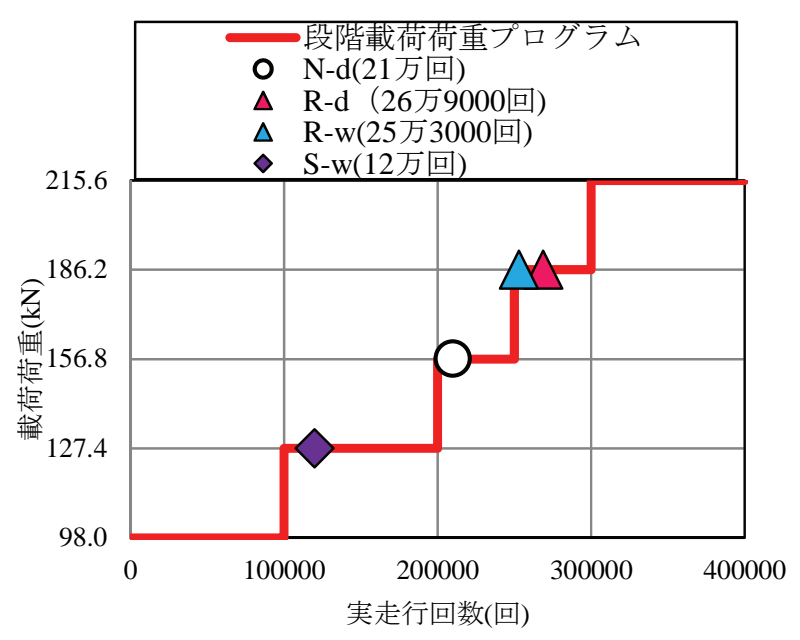

図-15 載荷荷重と実走行回数

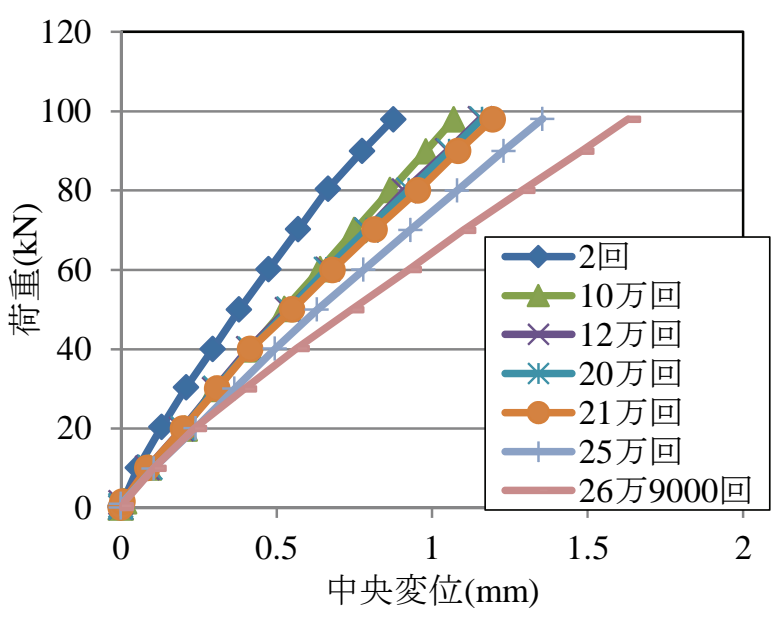

(b) R-d

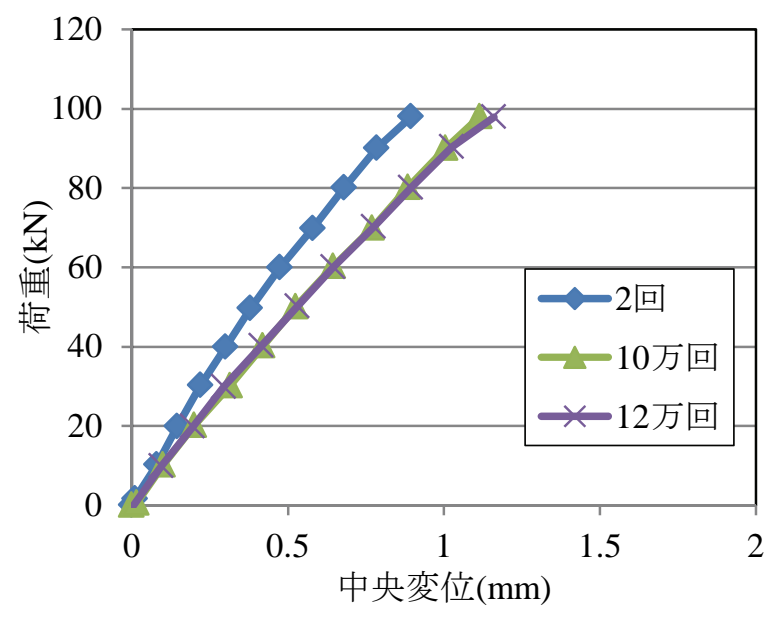

(d) S-W

図-16 基本荷重と中央変位の関係 


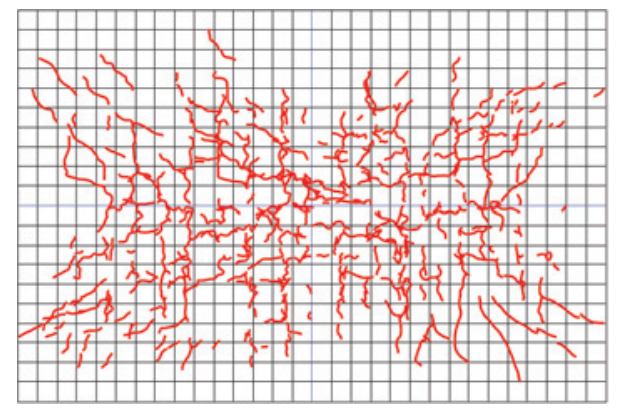

(a)N-d

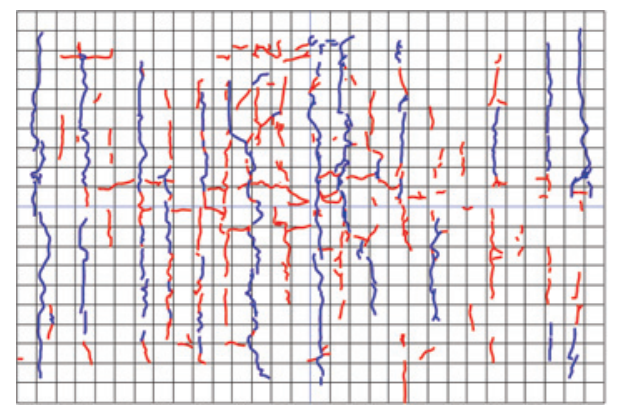

(c) $\mathrm{R}-\mathrm{w}$

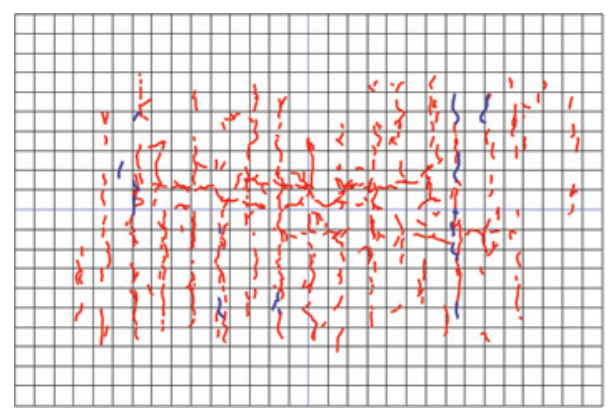

(b) R-d

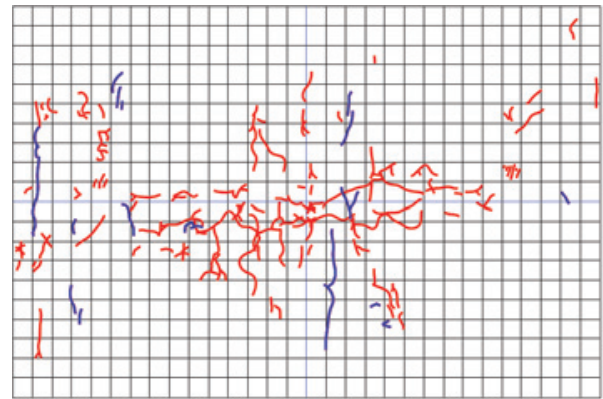

(d) S-w

図-17 床版下面のひび割れ発生状況(等価繰返し走行回数 : 10 万回)

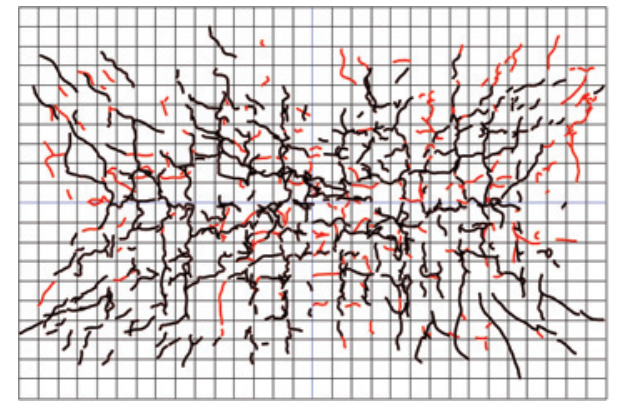

(a) N-d(700 万回)

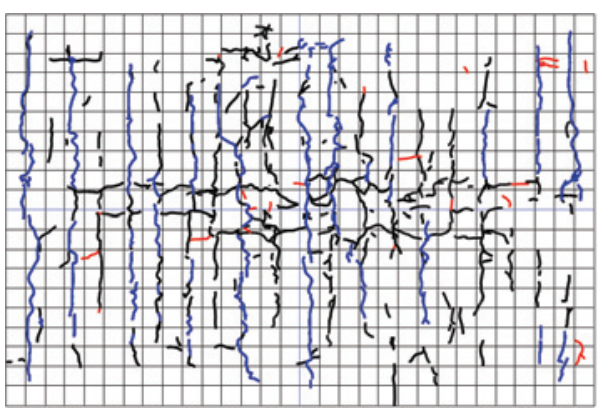

(c) R-w (3300 万回)

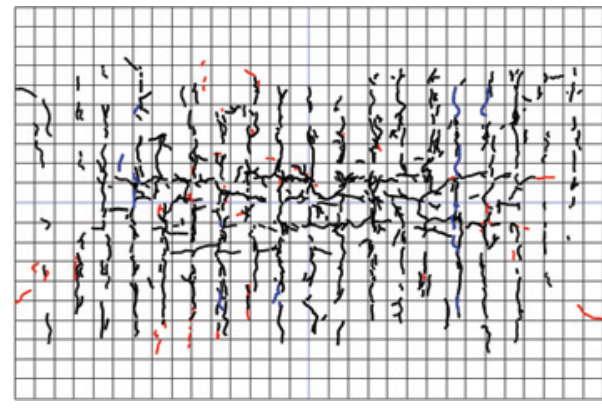

(b) R-d(9000 万回)

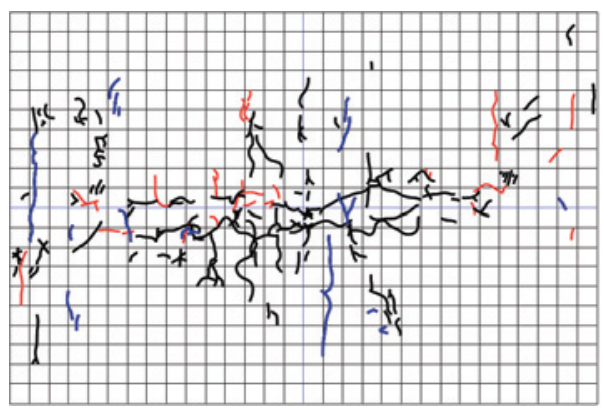

(d) S-w (67 万回)

図-18＼cjkstart床版下面のひび割れ発生状況(疲労限界状態時)

\section{4. 輪荷重走行試験による耐疲労性に関する検討}

\section{（1）段階載荷による輪荷重走行試験結果}

図-15に，輪荷重走行試験結果として，段階載荷によ る載荷荷重と疲労限界状態に達した際の実走行回数の関 係を示す。ここで，本研究における疲労限界状態は，既 往の研究8)より活荷重たわみが急増し始める状態とした.
また，疲労限界状態に至った走行回数は，活荷重たわみ が急増する直前に計測を実施した走行回数とした。なお， 輪荷重走行試験は，押抜きせん断破壊(床版下面が面外 方向に抜出し, 所定の荷重が載荷困難な状況)が生じる まで試験を継続させた。困より，N-dが実走行回数21万 回で疲労限界状態に達したのに対し，R-dでは26万9000 回，R-wは25万3000回と，急速試験を行った床版はいず 
れも健全な床版であるN-dよりも疲労限界状態に至る走 行回数が増加する結果であった。 一方で，S-wでは12万 回とN-dよりも早期に疲労限界状態に至った.このよう に，異なるASR促進に伴う損傷状況の違いによって，耐 疲労性に差が生じる結果を示し，次節よりASRがRC床 版の而疲労性に及ぼす影響を検討する.

\section{(2) 荷重と変位の関係}

図-16に，所定の回数ごとに静的載荷を行った際の基 本荷重(本研究では98kN) と床版中央変位の関係を示す. なお，静的載荷によるたわみの計測は基本的には走行回 数1万回ごとに計測を行い，試験初期段階および疲労限 界付近では，たわみの推移を明確に判断するため，短い 間隔で計測を行った。図より，走行回数2回では，N-dで 0.77mm, R-dで0.88mm, R-wで0.96mm, S-wで0.90mmと, ASR促進を行った床版ではいずれも健全なN-dよりたわ みが大きい結果を示した。これは，床版の下面および内 部に生じたひび割れにより岡性が低下したためと考えら れる.しかし，2回から10万回のたわみ量の増加は， ASR促進を実施した床版3体では0.2mm程度であったのに 対し， N-dではたわみ量の増加が $0.3 \mathrm{~mm}$ と最も大きい結 果を示した. これは，前述したケミカルプレストレスの 影響であると考えられ，ASR促進時において床版に導入 されたケミカルプレストレスが岡性の低下を抑制したと 推察される. その後のたわみ量の推移は, N-dでは輪荷 重走行回数および後述する床版下面に発生するひび割れ の増加に伴い, 徐々にたわみ量が増加していく傾向を示 し，ASR促進を行った床版ではいずれもたわみの増加が 小さい傾向を示した。 また，疲労限界状態におけるたわ み量は，N-dで1.74mm，R-dで1.63mm，R-wで1.31mm，Swで1.16mmと，水張り試験を実施したR-w，S-wでは剛性 が大きく低下することなく疲労限界状態に至る結果とな った.

\section{（3）床版下面におけるひび割れの発生状況}

図-17および図-18に，輪荷重走行試験の初期段階，途 中段階と, 疲労限界状態時における下面のひび割れの進 展状況を示す，供試体下面に発生したひび割れは，基本 的には走行回数5万回ごとに基本荷重 $98 \mathrm{kN}$ 載荷した状 態で行い，試験初期段階ではひび割れの進展を明確に把 握するため，短い間隔で観察を行った，なお，困中に示 すひび割れ線のうち，青線は輪荷重走行試験前に発生し ていたASRによるひび割れ(図-13参照)，黒線は本論文中 に示されるひび割れ困で，1つ前の段階までに観察され たひび割れ，赤線は括弧内に示す走行回数終了時で新た に観察されたひび割れを示している.

図-17より，走行回数10万回時のひび割れは，N-dでは

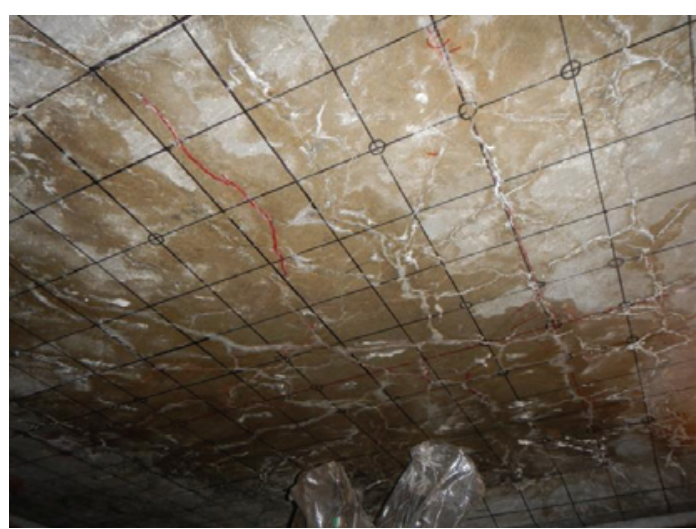

写真-10 ゲルの滲出(S-w)

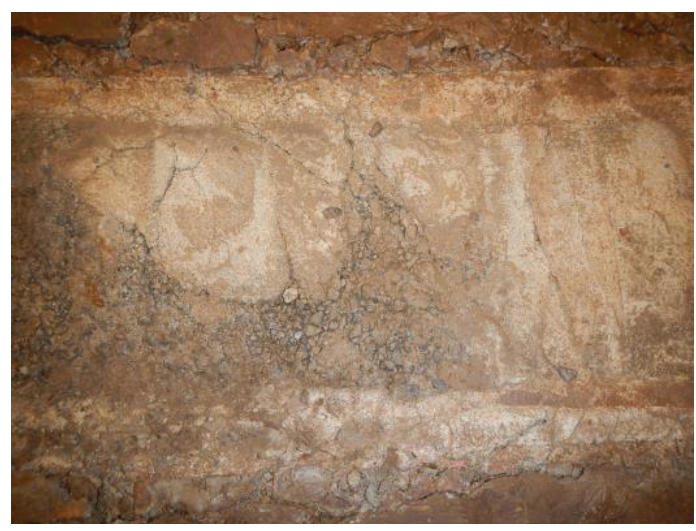

写真-11 コンクリートの砂利化(S-w)

輪荷重走行範囲を中心にひび割れが軸方向と軸直角方向 に進展を示したのに対して，急速試験を行ったR-dおよ びR-wでは，ASRによって生じたひび割れが連なるよう に進展する傾向を示した。一方で，S-Wでは，輪走行範 囲のみでひび割れが進展する傾向を示した.

図-18より，各床版の疲労限界状態時におけるひび割 れは，N-dでは，格子状にひび割れが形成され，床版下 面のひび割れ状況に基づく劣化進行過程は状態 $\mathrm{II}^{2}$ の劣 化期と類似のひび割れ状態を示した. これに対して， ASR促進を行った床版ではひび割れの進展が異なり，急 速試験を行ったR-dおよびR-wでは，いずれも主鉄筋方 向に生じたASRによって発生したひび割れが連なるよう に形成される傾向を示した. 一方で, 緩速試験を行った S-wでは，輪荷重走行範囲で局所的にひび割れが進展す る傾向を示し，生じたひび割れの本数も他の床版より明 らかに少ない状態であった。 なお，水張りを行った床 版では，R-wで等価繰返し走行回数1700万回時, S-wで等 価繰返し走行回数10万回時において床版下面で水染みが 確認され，押抜きせん断破壊後の床版下面では，写真10に示すようなでASRゲルの滲出, 床版上面では写真11に示すようなコンクリートの砂利化が観察された.

\section{(4) 共振周波数比の分布}

図-19から図-21に，輪荷重走行試験の各段階で計測し 


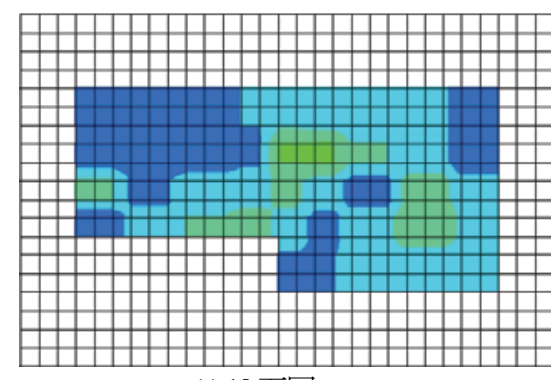

(a) 10 万回

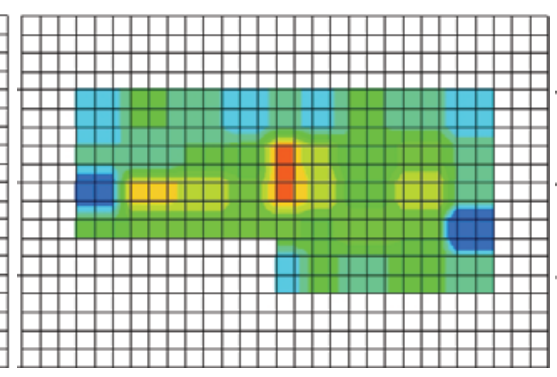

(b) 50 万回

図-19 共振周波数比の分布 $(\mathrm{N}-\mathrm{d})$

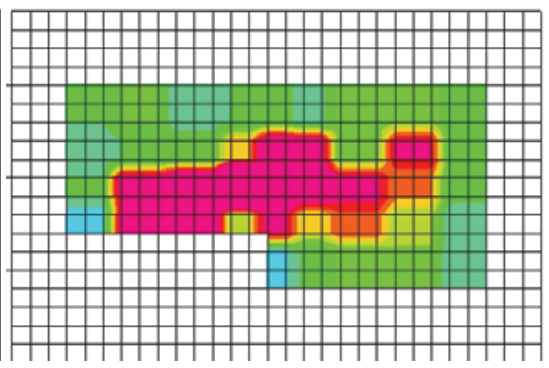

(c) 180 万回

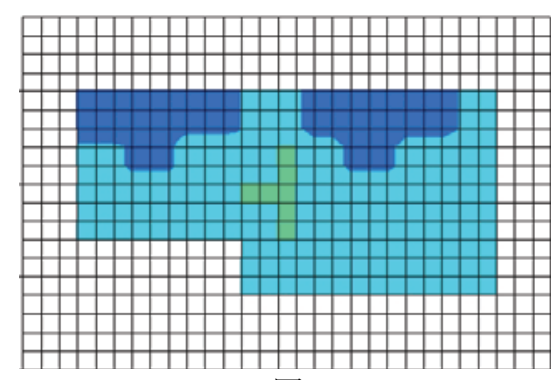

(a) 0 回

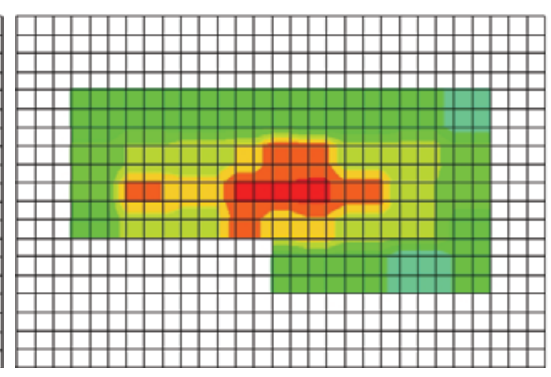

(b) 240 万回

図-20 共振周波数比の分布(R-d)

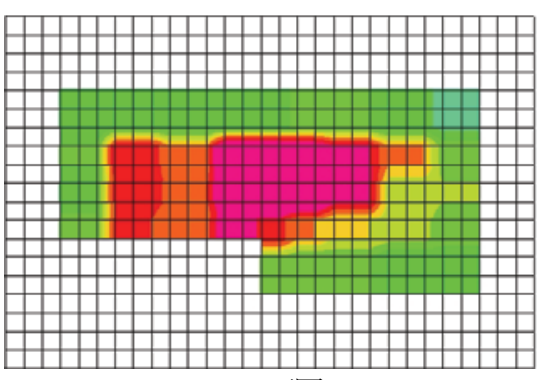

(c) 1800 万回

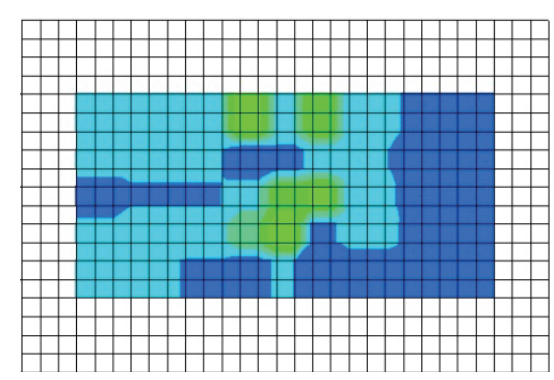

(a) 0 回

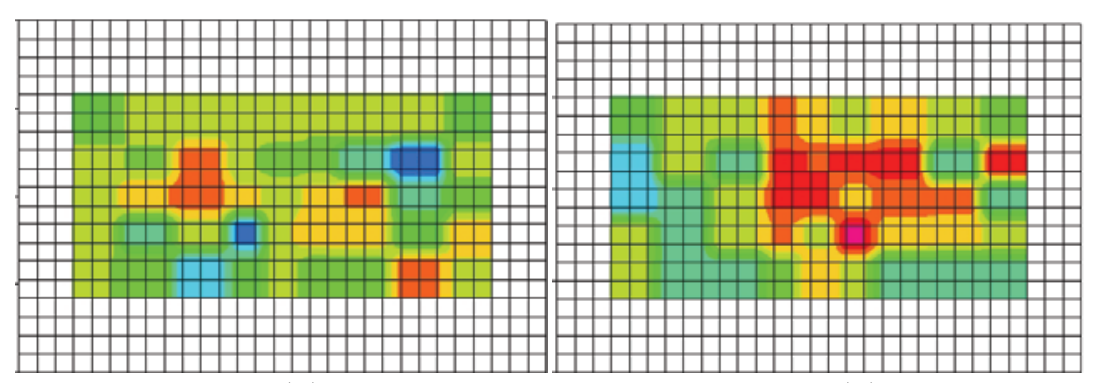

(b) 5 万回

図-21 共振周波数比の分布(S-w)

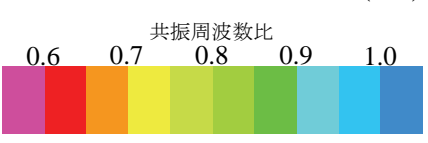

(c) 10 万回
た共振周波数比の分布を示す.ここで，共振周波数比と は，健全なRC床版における共振周波数の理論值と各段 階で計測された共振周波数との比である，なお，本実験 では，N-dの載荷試験前(走行回数0回時)における共振周 波数の計測を実施していないため, 健全なRC床版の共 振周波数の理論值を, N-d のテストピース $(\phi 100 \mathrm{~mm} \times$ 200mm)の密度と動弾性係数から式(3)を用いて求めた ${ }^{39}$.

$$
f=\frac{1}{2 L} \sqrt{\frac{E_{d}}{\rho}}
$$

ここで, $f:$ 共振周波数 $(\mathrm{Hz}), L$ : 床版厚さ $(\mathrm{mm}), E_{d}$ : 動 弾性係数 $\left(\mathrm{N} / \mathrm{mm}^{2}\right), \rho:$ コンクリートの密度 $\left(\mathrm{kg} / \mathrm{m}^{3}\right)$ である.

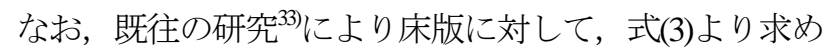
た理論值が，実測值とよく整合することが確認されてい る.これより，健全なRC床版の共振周波数の理論值は 10,596Hzであった.
図よりN-dでは，等価繰返し走行回数10万回までは供 試体全面において共振周波数比が 0.85 から 0.9 の範囲内に あり, 共振周波数比の低下は顕著でない. その後, 等価 繰返し走行回数 50 万回では輪荷重走行範囲内において共 振周波数比が 0.7 から 0.85 の範囲までに低下し, 供試体中 央位置では0.65と大きく低下した。これは，輪荷重の作 用する位置で疲労によるひび割れが進展した影響によっ て共振周波数比が低下したと考えられる. 等価繰返し走 行回数180万回では, 輪荷重走行範囲内全域で共振周波 数比が 0.6 程度となり, その後, 疲労限界状態に達した. R-dの走行回数 0 回では, 共振周波数比が概ね 1.0 を示寸範 囲が多く，床版全体の損傷度としては健全相当であった. しかし，床版中央位置については，共振周波数比が 0.85 程度を示寸箇所があり，ASRによる床版内部の損傷が見 られた．これは，前述したコンクリートのz方向のひず みが，床版端部よりも中央で大きくなることから，床版 
内部における損傷が床版中央で大きくなったと考えられ る. その後は, 等価繰返し走行回数 240 万回では床版中 央で共振周波数比が0.65程度まで低下し，等価繰返し走 行回数 1800 万回ではN-d同様に, 輪荷重走行範囲内全域 で共振周波数比が大きく低下し, 疲労限界状態に至った. 一方, 最も少ない走行回数で疲労限界状態に至ったS-w では，R-d同様に走行回数0回の段階では1.0を示す箇所が 多く，床版全体の損傷は大きくなかった. しかし，床版 中央位置では, 共振周波数比が 0.8 程度を示寸箇所が確 認された．このことから，前述した床版上下面と同様に， 床版内部においても，促進方法を変更することでひび割 れの発生形態に差異が生じたことが示唆された. その後 の走行回数に伴う共振周波数比の低下は, 床版内部の劣 化の進行程度が他の 2 体よりも顕著であり，等価繰返し 走行回数 5 万回時点では, 共振周波数比 0.6 程度を示寸箇 所が輪荷重走行範囲内にあり，等価繰返し走行回数 10 万 回時では輪荷重走行範囲の一部で共振周波数比が $0.6 を$ 下回る結果を示した。この共振周波数比の低下は，ASR によるひび割れと疲労損傷によって生じるひび割れの相 乗作用によるものだと考えられ，S-wでは載荷前で既に 発生していたASRによるひび割れが輪走行作用を受ける ことで増幅し，内部損傷が進行したと推察される.

以上のように，輪荷重走行試験の各段階で計測した共 振周波数比のマッピングを示すことによって，これまで 検出が困難であった床版内部の疲労損傷の進展状況を可 視化できた.

\section{(5) 断面損傷状況}

図-22に，輪荷重走行試験終了後に観察した橋軸方向 断面におけるひび割れ状態を示寸，なお，図中の網掛け
部はコンクリートが剥離および砂利化した位置を示して いる．図より，いずれの床版についても，上側主鉄筋位 置において耐疲労性を低下させる要因である像承ひび 割れ(図中の青線)の進展が見られた。また，ASRを受け た床版でもひび割れの進展に違いがあり，急速試験を実 施したR-d，R-wでは床版全長にひび割れが分散してい るのに対して, 緩速試験を実施したS-wでは, 輪荷重走 行範囲にひび割れが集中した。これは，前節で述べた共 振周波数比分布において, S-wの床版中央位置で局所的 に共振周波数比が低下している箇所と整合するような結 果であった. このことから，小型加振器を用いた強制振 動試験は, 床版内部の損傷状態を評価する上で有効な手 段であることが示唆された．また，S-wでは床版中央位 置において上面から下面にかけて貫通するようなひび割 れが発生しており, 床版内部で局所的に疲労損傷が進行 し，そこに床版上面から水の浸入があったことで早期に 破壞に至った可能性があると考えられる。

なお，供試体断面の観察時において，全ての床版で鉄 筋の破断や降伏には至っておらず，鉄筋の定着は十分に 確保されていたことを確認している.

\section{（6）活荷重たわみと等価繰返し走行回数の関係}

図-23に活荷重たわみと等価繰返し走行回数の関係を 示寸，また，図中には疲労破壊に到る直前の走行回数ま でをプロットしている，なお，活荷重たわみは，走行回 数2回後を初期值としてその変化を示した.

図上り, 輪荷重走行試験開始直後(等価繰返し走行回 数2回)の活荷重たわみは, N-dで0.77mmであるのに対し, ASR促進を行った床版では, R-dで 0.92mm, R-wで 0.96mm，S-wで0.90mmと，いずれも初期の活荷重たわみ

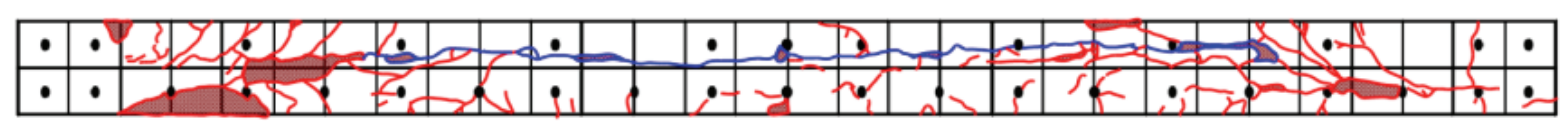

(a)N-d

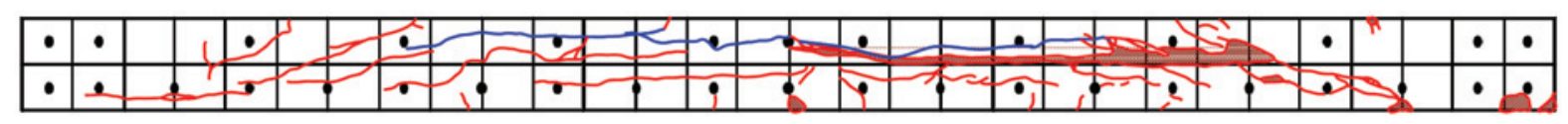

(b) R-d

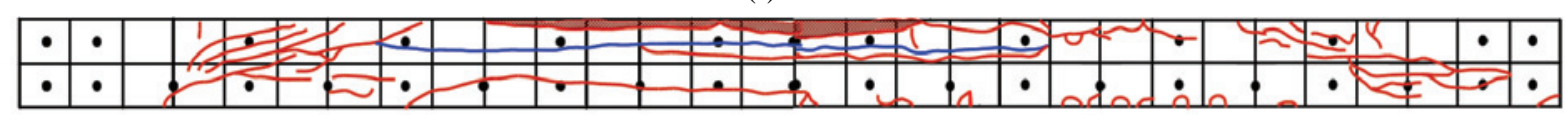

(c) R-w

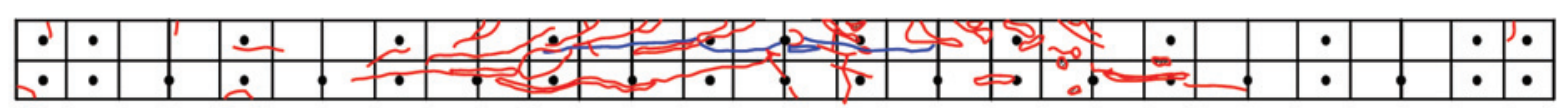

(d) S-w

図-22 床版軸方向断面の損傷状況 
が大きい結果を示した.これは, ASRにより床版に導入 されたケミカルプレストレスの影響と，床版下面および 床版内部に発生したひび割れの大小関係によるものだと 考えられ，載荷初期の剛性に関しては，ケミカルプレス トレスの影響以上に床版に発生したひび割れの影響が大 きかったことで岡性が低下したと考えられる.しかし， その後の活荷重たわみの増加傾向は，それぞれの床版で 異なった。.まず， N-dでは，等価繰返し走行回数の増加 とともに活荷重たわみも増加する傾向で，等価繰返し走 行回数が約 700 万回で疲労限界状態に達した. これに対 して急速試験を実施したR-dおよびR-wでは，等価繰返 し走行回数 1000 万回までは, 等価繰返し走行回数の増加 に対する活荷重たわみの増加量はN-dよりも小さい傾向 を示した. これは，前述したケミカルプレストレスによ って，剛性の低下が抑制されたためと考えられる．等価 繰返し走行回数 1000 万回以降は, 徐々に活荷重たわみが 増加する傾向を示し，R-dでは9000万回，R-wでは3300万 回で疲労限界状態に至る結果となり，N-dよりも走行回 数が増加する結果を示した. これまでに，高温高湿度環 境下においてRC部材に対してASR促進を実施した場合, 静的な耐荷力が健全なRC部材よりも向上寸るといった 研究成果 ${ }^{20}$ が報告されているが，輪荷重が作用する移動 繰返し載荷実験においても，既往の研究と同様にケミカ ルプレストレスの作用で耐疲労性が向上する結果を示し た.また，水張り試験を実施したR-wでは疲労限界に達 する走行回数がR-dの約1/4であり, 而疲労性が大きく低 下寸る結果を示した。 これは，子田らの研究411において， 健全な供試体に対して水張り試験を実施した場合, 疲労 限界状態に達する走行回数が乾燥状態で試験を行った供 試体の約 $1 / 4$ となるといった実験結果と整合する結果で あり，本実験においても水の作用により，耐疲労性が低 下したと考えられる.

緩速試験を実施したS-wでは，等価繰返し走行回数に 対する活荷重たわみの推移はR-d，R-wと同様の傾向を 示した. しかし，等価繰返し走行回数67万回で活荷重た わみが急激に立ち上がり，他の床版よりも明らかに少な い走行回数で疲労限界に至る結果を示した. 疲労限界に 至った走行回数を健全供試体と比較すると，S-wは健全 供試体の約 $1 / 15$ の走行回数で疲労限界に至っており, 前 述した水作用の影響以上に而疲労性が低下寸る結果であ った.

このように, 疲労限界状態に達する等価繰返し走行回 数は, 促進試験の方法で大きく異なり, 急速試験でASR を進行させた床版では，ケミカルプレストレスの影響に より，健全な床版よりも耐疲労性が向上した．反対に， 緩速試験でASR促進を進行させた床版では，ケミカルプ レストレスが急速試験を行った床版の半分程度であり,

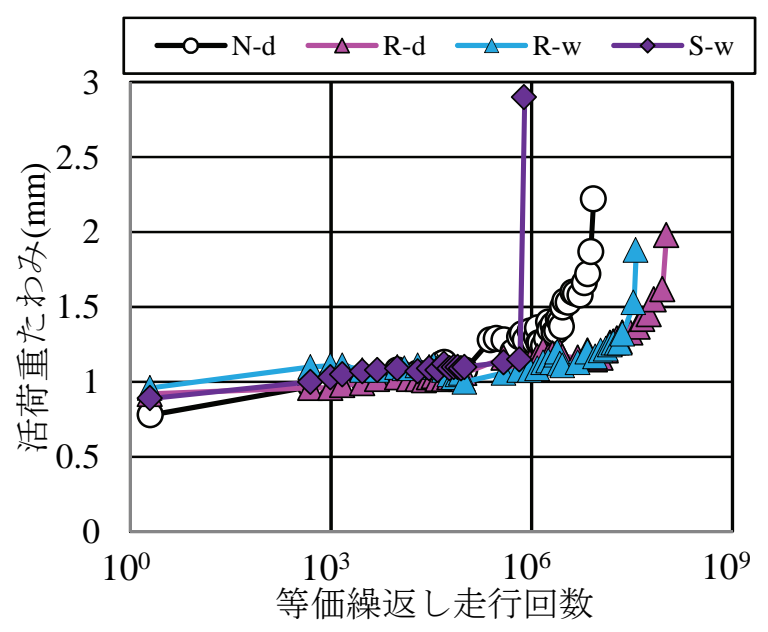

図-23 活荷重たわみと等価繰返し走行回数の関係

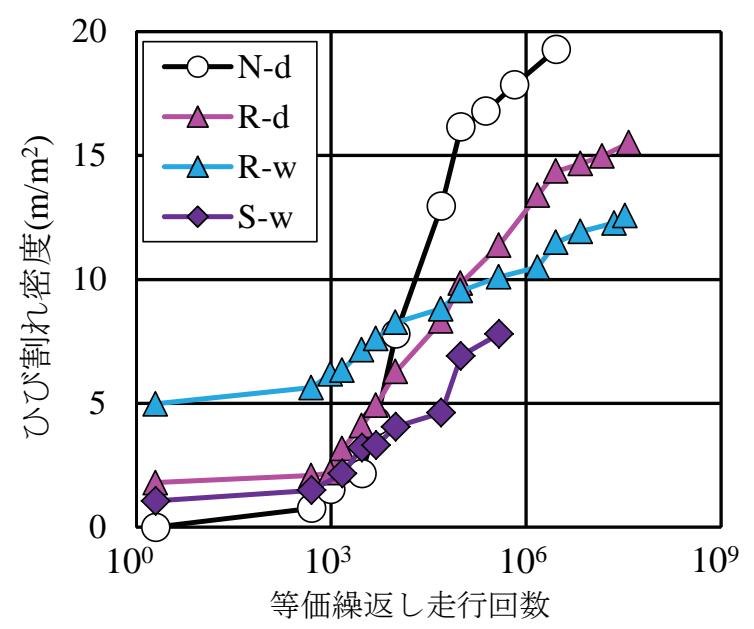

図-24 ひび割れ密度と等価繰返し走行回数の関係

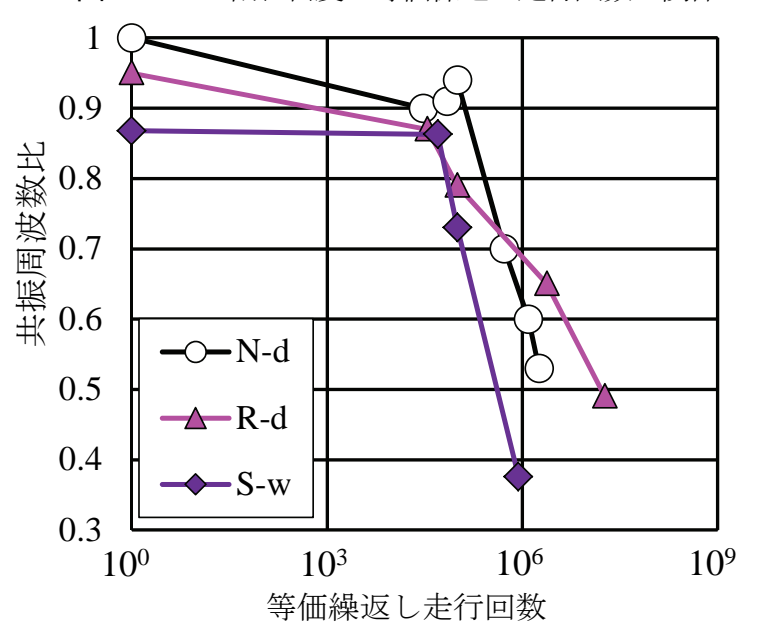

図-25 床版中央の共振周波数比と等価繰返し走行回数の関係

ケミカルプレストレスの影響以上にASRによるコンクリ 一ト内部の劣化の影響が大きく, 健全な床版よりも而疲 労性が大きく低下した．また，S-wについては，主鉄筋 方向のコンクリート膨張量が静的な耐荷力には影響の少 ないとされる範囲であっても，本実験においては，而摭 労性が大きく低下寸る結果を示した. 
つまり，一般に，ASRにより劣化を生じたコンクリー トでは, 膨張量の増加に伴い土縮強度や圧縮疲労強度が 低下寸ると考えられるが ${ }^{11,422}$, RC部材の而疲労性につい ては，ASRによるコンクリートや鉄筋のひずみのみなら ず, 床版内部のひび割れ状況や水の存在の有無といった 要因により評価することが重要であることが示唆された。

\section{(7) ひび割れ密度と等価繰返し走行回数の関係}

図-24に，床版下面に発生したひび割れの密度と等価 繰返し走行回数の関係を示寸，図より，N-dでは，走行 回数約 1 万回程度から密度が急激に立ち上がり, その後 は緩やかに増加する結果となった。これに対して, ASR 促進を実施した床版では，ひび割れ密度の増加傾向がそ れぞれ異なった．急速試験を行ったR-dおよびR-wでは, $\mathrm{N}-\mathrm{d}$ りも等価繰返し走行回数に伴うひび割れ密度の増 加が小さい傾向を示した. これは，ケミカルプレストレ スの影響により, 輪荷重によるひび割れの発生が抑制さ れたためと考えられる. また，R-wでは，R-dよりも初 期のひび割れが多く発生していたものの, 疲労限界状態 においてはR-dよりも小さい密度を示した。これは, ASRによるひび割れが多く発生し, 輪荷重走行試験前で 既にひび割れ網がほぼ定まっていたことで，新たなひび 割れが生じにくい状態であったと推察される. 一方で, S-wでは，ひび割れ密度の増加量が他の3体よりも明らか に小さい傾向を示し, 表面上ひび割れの発生が多くない 状態で疲労限界に至った. S-wでは前述した床版下面の 観察により, 輪荷重走行範囲に集中していたことが確認 されており，またASRによるひび割れの幅も他の床版に 比して大きかった. このことから，ASR促進時において 発生した幅の大きなひび割れが支配的となり, 輪走行作 用によるひび割れの分散性が著しく低下し, 輪走行範囲 直下で局所的にひび割れが進展したことで，急激な疲労 破壊に至ったものと考えられる.

\section{（8） 共振周波数比と等価繰返し走行回数の関係}

図-25に床版中央位置で計測した共振周波数比と等価 繰返し走行回数の関係を示す. 図より, まず走行回数 0 回時の共振周波数比は, R-d 70.95, S-wで0.86と, ASR促 進を実施した床版ではいずれも載荷前において共振周波 数比が低下している. これは, 前述の通り, ASRにより 床版内部に発生したひび割れが共振周波数比を低下させ たためと推察される，その後，N-dおよびR-dでは，等価 繰返し走行回数 10 万回までは, 走行回数の増加に伴い共 振周波数比が徐々に低下寸る傾向を示した. この区間で は, 前述した床版下面に発生するひび割れの進展が先行 しているが，これは，床版表面で観察されるひび割れの 向きが床版に対して垂直であり, 加振方向と同じである
ために，振動試験に与える影響が小さかったと推察され る. 等価繰返し走行回数 10 万回から約 300 万回において は，共振周波数比が 0.6 程度まで大きく低下した。 この 時, N-dのひび割れ密度の増加は緩やかになっているこ とから, 疲労荷重によってひび割れが床版内部で進展し たことで周波数が低下したと考えられる. その後, 等価 繰返し走行回数約 300 万回以降では，N-d, R-d ともに活 荷重たわみおよびひび割れ密度の増加は緩やかであるの に対し, 共振周波数比は 0.5 程度まで低下寸る傾向を示 した.

次にS-wでは, 等価繰返し走行回数5万回時では, 他の 2体と同様に共振周波数の低下は見られなかった。等価 繰返し走行回数 5 万回から 10 万回までの区間では, 活荷 重たわみとひび割れ密度が低い值で推移しているが，共

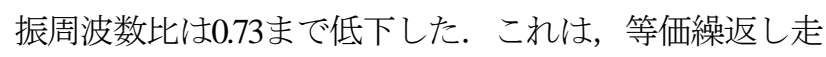
行回数 10 万回時点で, 床版内部におけるひび割れが他の 2体よりも進展したと考えられ, 強制振動試験による共 振周波数比を把握することで, 床版内部の劣化性状を推 定できる可能性が示唆された，その後，等価繰返し走行 回数約67万回で活荷重たわみが急増し, 疲労限界状態に 至った．なお，S-wの押抜きせん断破壊後における床版 中央位置の共振周波数比は 0.38 であった.

\section{5. まとめ}

本研究により得られた主な結果を以下に示す.

（1）ASRにより劣化した道路橋RC床版は，ASRの促進 方法により床版の損傷状況および而疲労性が大き く異なった．急速にASRを促した床版では，ケミ カルプレストレスの影響により健全な床版に比心゙ て耐疲労性がむしろ向上し, 反対に, 緩やかに ASRを促した床版では，耐疲労性が大きく低下寸 る結果となった。一般に, ASRを生じたコンクリ ートでは, 膨張量の増加に伴いヤング係数, 圧縮 強度や圧縮疲労強度が低下寸ると考えられるが, RC床版では，ASRによるコンクリートや鉄筋のひ ずみのみならず，床版内部のひび割れ状況や水の 存在の有無といった要因によりその耐疲労性が定 まることが示された.

（2）ASRを緩やかに促進させた床版は，急速に促進さ せた床版よりも，コンクリートの膨張量および床 版に導入されるケミカルプレストレスは小さく目 視可能なひび割れの発生も顕著でなかった. しか し，顕微鏡では微細なひび割れが観察されており， ASR促進後の段階で共振周波数が明らかに低下し た。このことから，ASRを緩やかに促進させた場 
合，床版内部に微細なひび割れが発達し，これが 床版の見かけの剛性を低下させる要因であること が示唆された。

（3）ASR促進を実施した床版では，いずれもASRによる ひび割れが支配的となり，その後の疲労による新 たなひび割れの発生が抑制される傾向を示した.

特に，ASRを緩やかに促進させた床版では，ASRに より発生した幅の大きなひび割れの影響により， 疲労によるひび割れの分散性がそしく，その後の 輪荷重走行試験では，輪走行範囲直下で局所的に ひび割れが進展し，急激な疲労破壊に至る傾向を 示した.

（4）強制振動試験結果より，疲労損傷の各段階におい て複数点の共振周波数比を計測することで，部材 の損傷レベルの評価および損傷範囲の推定が可能 であることが示された．特に，活荷重たわみや床 版下面に発生するひび割れでは疲労限界状態に至 る直前までその兆候が表れないのに対して，共振 周波数比では早い段階で低下傾向が認められ，床 版内部の疲労損傷を検知する上で有効な手法とな り得ることが明らかになった。

本研究は国内外でも例を見ない大規模かつ独創的な実 験手法により，実物大RC床版供試体を用いてASR促進 試験，および輪荷重走行試験を行い，ASRの促進方法が RC床版の損傷度および而疲労性に影響を及ぼすことを 明らかにした点で意義があると思われる．しかし，ASR がRC床版の耐疲労性に及ぼす影響に関する研究は端緒 に就いたばかりであり，未だ未解明な部分が数多く存在 する．特に，実環境ではASRと疲労が同時に作用するた め，今後は実環境におけるASRと疲労の劣化進行過程を 踏まえた実験を実施する必要がある。本研究ではASR促 進試験後に輪荷重走行試験を行ったが，まとめ(3)に示 寸通り，ASRにより発生したひび割れが支配的となり， その後の疲労による新たなひび割れの進展が抑制される という結果を得た．従って，今後は予備載荷として輪荷 重走行試験によりあらかじめ疲労によるひひ割れを発生 させた後にASR促進試験, さらには輪荷重走行試験(本 載荷)を行い，ASRによるひび割れの進展状況とその後 の疲労破壊に至る過程を究明する予定である．以上の実 験データを3次元非線形有限要素解析モデル43)に反映さ せることにより, 将来的には解析により凍結防止剂散布 下においてASRを受けたRC床版の耐疲労性について評 価することが可能になると思われる.

謝辞: 本研究は, 一般財団法人 土木研究センター, 太 平洋セメント(株), 住友大阪セメント(株), 金沢大学(久 保善司准教授), および東北大学との共同研究として行
われ，一部実験の実施にあたっては科学研究費(課題番 号: 24360184)の助成を受けた. また, 本研究は日本大学 工学部土木工学科コンクリート工学研究室の多くの学生 が携わった成果をまとめたものである.さらに，本研究 を進めるにあたり, 前川宏一教授（東京大学大学院）, 田中泰司特任准教授（東京大学生産技術研究所），高橋 佑弥助教（東京大学大学院）より有益な御助言を賜りま した.ここに記して感謝の意を表します。

\section{参考文献}

1) 松井繁之：道路橋床版 設計・施工と維持管理, 森北 出版, 2007.

2) 土木学会 : 2007 年制定コンクリート標準示方書【維 持管理編】, 2008.

3) 日本コンクリート工学協会: 融雪剤によるコンクリ 一下構造物の劣化研究委員会報告書・論文集, 1999.

4) 土木学会：コンクリート技術シリーズ No. 71 材料劣 化が生じたコンクリート構造物の構造性能, 2006.

5) 三田村浩, 佐藤京, 本田幸一, 松井繁之: 道路橋 RC 床版上面の凍害劣化と疲労寿命一の影響, 構造工学 論文集, Vol. 55A, pp. 1420-1431, 2009.

6) 子田康弘, 古山幸永, 岩城一郎 : 塩害を受けた RC 床 版の劣化性状と耐荷性状に関する実験的検討，コン クリート工学年次論文集, Vol. 30, No. 1, pp. 813-818, 2008.

7) 田附伸一, 津吉毅, 石橋忠良, 松田芳範, 今井勉: ASR により損傷した RC 部材の耐荷力に関する実験 的研究, 土木学会論文集 E, Vol. 63, No. 1, pp. 166-177, 2007.

8) 前島拓, 子田康弘, 土屋智史, 岩城一郎：塩害によ る鉄筋腐食が道路橋 RC 床版の而摭労性に及ぼす影響, 土木学会論文集 E2, Vol. 70, No. 2, pp. 208-225, 2014.

9) 例えば小野貴之, 三田村浩, 林川俊郎, 松井繁之： 積雪寒冷地における RC 床版の疲労耐久性に関寸る研 究, 第 6 回道路橋床版シンポジウム論文報告集, pp. 75-80, 2008.

10）例えば小野貴之, 三田村浩, 林川俊郎, 松井繁之： 積雪寒冷地における RC 床版の疲労耐久性向上につい て, 構造工学論文集, Vol. 55A, pp. 1432-1441, 2009.

11) 土木学会：アルカリ骨材反応対策小委員会報告書, 2005.

12) 大深伸尚, 鳥居和之, 池富修, 川村満紀 : 鉄筋コン クリート堤体の耐久性調査, コンクリート工学年次 論文集, Vol. 22, No. 1, pp. 43-48, 2000.

13）小林一輔, 丸章夫, 立松英信 : アルカリ骨材反応診 断, 森北出版, 1991.

14）上原伸郎, 幸左賢二, 大代武志, 山口和成 : 複数の 鉄筋破断が生じた ASR 実構造物の鉄筋損傷評価, 構 造工学論文集, Vol. 59A, pp. 866-877, 2013.

15）五島孝行，大田孝二，梶尾聡，鈴木康範，井戸康清， 島田守：アルカリ骨材反応で損傷した道路橋床版の 調查, 土木学会第 68 回年次学術講演会講演概要集, pp. 835-836, 2013.

16) 久保善司, 佐古崇, 川崎文義, 横山広 : 床版部材の ASR 膨張挙動と FRP シート貼付けによる膨張抑制, コンクリート工学年次論文集, Vol. 31, No. 1, pp. 
1243-1248, 2009.

17) 小林和夫 : アルカリ骨材反応を生じた部材や構造物 の耐荷重性能一はり部材一, コンクリート工学, Vol. 24, No. 11, pp. 70-78, 1986.

18）棚橋和夫，岩永武士，小柳洽，浅野幸夫：ASR によ って劣化した RCはりおよび柱の力学挙動について, コンクリート工学年次論文報告集, Vol. 18, No. 1, pp. 843-848, 1996.

19) 小柳洽, 六郷恵哲, 内田裕市, 長瀬道雄 : 著しい AAR 損傷を生じた RC はりの挙動, コンクリート工 学年次論文報告集, Vol. 15, No. 1, pp. 947-952, 1993.

20) 小柳洽, 六郷恵哲, 石田裕哉 : アルカリ骨材反応に よるひびわれと RC 部材の性状，セメント技術年報， No. 39, pp. 352-355, 1985.

21）岩波光保，横田弘，鳥居和之，鈴木義晃，奥山和 俊 : アルカリ骨材反応により損傷したコンクリート 部材の力学挙動之補強方法に関する提案, 港湾技研 資料, No. 994, 2001.

22）松田豊樹，森川英典，王健：ASR が生じた RC 部材 のせん断耐荷性に関する実験的検討，神戸大学大学 院工学研究科・システム情報学研究科紀要, 第 3 号, pp. 23-31, 2011.

23) 小林孝元, 田中泰司：アルカリ骨材反応による劣化 の進行した RC 床版の押し抜きせん断試験，コンクリ 一ト構造物の補修・補強, アップグレード論文報告 集，第 13 巻, pp. 259-264, 2013.

24) 久保善司, 山本晋, 服部篤史, 宮川豊章 : ASR がコ ンクリート曲げ部材の而荷性状に与える影響, 材料, Vol. 50, No. 9, pp. 1013-1020, 2001.

25) 例えば, 久保善司, 上田隆雄, 黒田保, 野村倫一： アルカリ骨材反応による膨張がコンクリートの力学 的性能に与える影響, コンクリート工学年次論文集, Vol. 28, No. 1, pp. 1691-1696, 2006.

26) 日本道路協会 : 道路橋示方書 - 同解説(鋼橋編), 2002.

27）五島孝行，太田孝二，岸良竜，大野晃，前島拓，久 保善司 : アルカリシリカ反応と輪荷重疲労で複合劣 化した床版の疲労耐久性，土木技術資料 56-12, pp. 60-63, 2014.

28）五島孝行, 岸良竜, 大野晃, 前島拓: 反応性粗骨材 を用いた道路橋床版の輪荷重走行試験, 第 8 回道路 橋床版シンポジウム論文報告集, pp. 1-6, 2014.

29) 広中憲, 大西弘志, 横山広, 関口幹夫, 堀川都志 雄 : 道路橋 RC 床版の疲労耐久性を評価するための試 験方法について，第 3 回道路橋床版シンポジウム講 演論文集，pp. 17-24, 2003.

30) 土木学会 : 道路橋床版の設計の合理化と耐久性の向 上, 2004.

31) 松井繁之 : 橋梁の寿命予測一道路橋 RC 床版の疲労寿
命予測, 安全工学, Vol. 30, No. 6, pp. 432-440, 1996.

32) 内藤英樹, 大竹雄介, 齊藤知廣, 鈴木基行 : 振動試 験に基づくコンクリート部材の損傷同定に関する基 礎的検討, コンクリート工学年次論文集, Vol. 33, No. 2, pp. 949-954, 2011.

33) 内藤英樹, 齊木佑介, 鈴木基行, 岩城一郎, 子田康 弘，加藤潔：小型起振機を用いた強制加振試験に基 づくコンクリート床版の非破壊試験法, 土木学会論 文集 E2, Vol. 67, No. 4, pp. 522-534, 2011.

34）宮村正樹, 子田康弘, 内藤英樹, 岩城一郎, 鈴木基 行: 振動特性に着目した RC 床版の疲労損傷度評価手 法に関する研究, 構造工学論文集, Vol. 57A, pp. 1251-1262, 2011.

35）長松昭男：モード解析入門，コロナ社，2009.

36) 前島拓, 内藤英樹, 子田康弘, 岩城一郎, 鈴木基 行 : 共振周波数の低下に着目した実道路橋 RC 床版の 疲労損傷度評価, 構造工学論文集, Vol. 61A, pp. 777787, 2015.

37) 土木学会 : 2007 年制定コンクリート標準示方書【設 計編】, 2008.

38) Takahashi, Y., Shibata, K. and Maekawa, K. : ChemoHygral Modeling of Structural Concrete Damaged by Alkali silica Reaction, Proceedings of the 1st Ageing of Materials \& Structures 2014 Conference, pp. 424-431, 2014.

39）内藤英樹，大竹雄介，渡邊孝和，鈴木基行，中野聡， 岩城一郎, 木血尚宏：反共振周波数に着目したはり の損傷位置同定に関寸る基礎的研究, 構造工学論文 集, Vol. 58A, pp. 150-161, 2012.

40) 横山広, 浦修造, 関口幹夫, 堀川都志雄 : 床版の劣 化現象および床版補強工法に関する解析的検討，コ ンクリート工学年次論文集, Vol. 32, No. 2, pp. 451456, 2010.

41) 子田康弘, 斉藤卓也, 岩城一郎：輪荷重走行試験に よる材料劣化を受けた道路橋 RC 床版の疲労耐久性評 価, コンクリート構造物の補修, 補強, アップグレ 一ド論文報告集，第 9 巻，pp. 145-150, 2009.

42) 宇治公隆, 梁俊, 新道竹文, 王鋭 : アルカリシリカ 反応による劣化を生じたコンクリートの圧縮疲労条 件下における寿命予測, 土木学会論文集 E, Vol. 65, No. 2, pp. 259-270, 2009.

43）例えば, 土屋智史, 牧剛史, 斉藤成彦, 渡邊忠朋, 前川宏一 : 非線形有限要素解析による RC 面部材の損 傷指標之耐力評価，土木学会論文集 E2, Vol. 68, No. 3, pp. 209-224, 2012.

(2015. 3. 24 受付) 


\section{INFLUENCE OF ALKALI SILICA REACTION ON FATIGUE RESISTANCE OF RC BRIDGE DECK}

\section{Takuya MAESHIMA, Yasuhiro KODA, Ichiro IWAKI, Hideki NAITO, Ryo KISHIRA, Yasunori SUZUKI, Koji OHTA and Motoyuki SUZUKI}

This study aims at investigating an influence of alkali-silica reaction (ASR) on fatigue resistance of RC bridge deck. Firstly, using full-sized RC deck specimens, two types of ASR accelerated tests were performed by varying the environmental condition of ASR. Then, a wheel load trucking test was conducted focusing on the presence or absence of water on upper-surface of the specimen. In this experiment, the deflection and crack patterns of RC deck specimen in each number of trucking were measured, and the degradation of stiffness due to ASR and fatigue was evaluated by forced vibration test using small vibration device. As a result, it was revealed that the fatigue resistance of RC bridge deck by ASR depended on the environmental condition of ASR, which was assumed due to the introduction of chemical prestress by ASR, and the interaction of crack propagation and water action. Furthermore, the vibration test proved useful in evaluating the fatigue resistance of RC bridge deck by ASR. 